GAO Report to Congressional Committees

November 2005

\title{
DRUG CONTROL
}

Agencies Need to Plan for Likely Declines in Drug Interdiction

Assets, and Develop Better Performance Measures for Transit Zone Operations

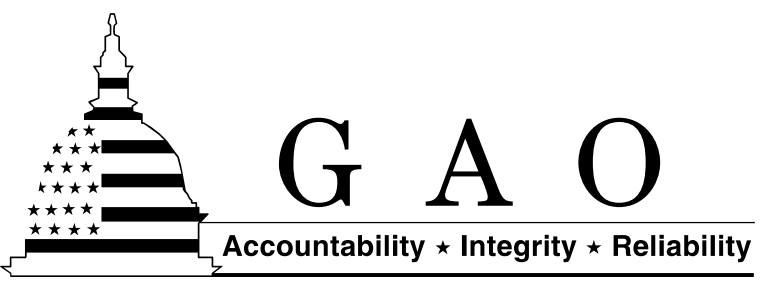




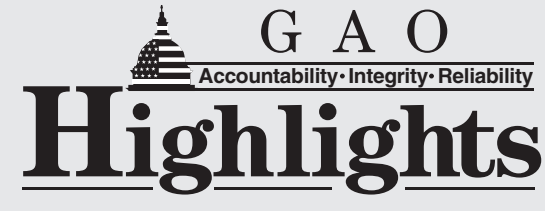

Highlights of GAO-06-200, a report to congressional committees

DRUG CONTROL

\section{Agencies Need to Plan for Likely Declines in Drug Interdiction Assets, and Develop Better Performance Measures for Transit Zone Operations}

\section{Why GAO Did This Study}

One of the U.S. National Drug Control Strategy's priorities is to disrupt the illicit drug market. To this end, the Departments of Defense and Homeland Security provide ships and aircraft to disrupt the flow of illicit drugs, primarily cocaine, shipped from South America through the Caribbean Sea and eastern Pacific Ocean-an area known as the transit zone. The Office of National Drug Control Policy (ONDCP) oversees the U.S. anti-drug strategy. The Joint Interagency Task Force-South (JIATF-South) directs most transit zone operations. We examined U.S. efforts to interdict maritime movements of cocaine. We analyzed the (1) changes in cocaine seizures and disruptions since calendar year 2000, (2) trends in interdiction assets provided since fiscal year 2000, (3) challenges to maintaining transit zone interdiction operations, and (4) performance measures the agencies use to assess their progress.

\section{What GAO Recommends}

We recommend that Defense and Homeland Security (1) plan for likely declines in interdiction assets and (2) develop measures with ONDCP to better assess interdiction operations. We also recommend that ONDCP address prior recommendations to improve drug data. The agencies generally agreed, but did not detail when and how they will address these recommendations.

www.gao.gov/cgi-bin/getrpt?GAO-06-200.

To view the full product, including the scope and methodology, click on the link above. For more information, contact Jess T. Ford at (202) 512-4268 or FordJj@gao.gov.

\section{What GAO Found}

Cocaine seizures and disruptions in the transit zone have increased about 68 percent since calendar year 2000-from 117 metric tons in 2000 to 196 metric tons in 2004. About two-thirds of the disruptions were in the western Caribbean Sea and eastern Pacific Ocean where the United States has most of its interdiction assets. JIATF-South and other cognizant officials attribute the increase to improved interagency cooperation and intelligence, the introduction of armed helicopters to stop go-fast boats, and increased cooperation from nations in the region.

Since fiscal year 2000, the availability of assets-ships and aircraft-to disrupt drug trafficking in the transit zone have varied. On-station ship days peaked in fiscal year 2001 and flight hours peaked in 2002, but both have generally declined since then, primarily because the Department of Defense has provided fewer assets. Declines in Defense assets have been largely offset by the Coast Guard, Customs and Border Protection (CBP), and certain allied nations. Nevertheless, in recent years, JIATF-South has detected less than one-third of the "known and actionable" maritime illicit drug movements in the western Caribbean Sea and eastern Pacific Ocean. Yet, once detected, over 80 percent of the drug movements were disrupted.

Various factors pose challenges to maintaining the current level of transit zone interdiction operations. The reduced availability of the U.S. Navy's P-3 maritime patrol aircraft due to structural problems will degrade the U.S. capability to detect suspect maritime movements, readiness rates of older Coast Guard ships have declined since fiscal year 2000, and the surface radar system on the Coast Guard's long-range surveillance aircraft is often inoperable. Coast Guard and CBP officials also noted that they may not be able to sustain their level of assets in light of budget constraints and other homeland security priorities that may arise. These officials expressed concern that the long-term implications of likely declines in transit zone assets have not been addressed.

The Government Performance and Results Act of 1993 requires agencies to develop performance measures to assess progress in achieving their goals. The Coast Guard's measures relate to reducing cocaine flow through the transit zone, CBP's planned measures are not specific to the transit zone, and Defense's planned measures focus on the number of disruptions of cocaine movements. But data that would help in assessing transit zone interdiction operations are problematic. For instance, in its assessment for 2004, ONDCP reported that between 325 metric tons and 675 metric tons of cocaine may be moving towards the United States. Such a wide range is not useful for assessing transit zone interdiction operations. In addition, data on U.S. drug usage are difficult to obtain and often cannot be generalized to the United States. In a 2001 report for ONDCP, the National Research Council made similar observations and recommended ways to improve the collection and analysis of illicit drug data, but ONDCP has not fully addressed them. 


\section{Contents}

\section{Letter}

Results in Brief

Background

Several Factors Have Contributed to the Increase in Cocaine

Seizures and Disruptions

Availability of Assets Provided for Interdiction Operations Have

Varied Since Fiscal Year 2000

Challenges in Maintaining Interdiction Operations

Agencies' Performance Measures Vary and Data for Assessing

Performance Are Problematic

Conclusions

Recommendations for Executive Action

Agency Comments and Our Evaluation

Appendix I: Scope and Methodology 35

Appendix II: Counternarcotics Maritime Law Enforcement Agreements 39

Appendix III: Comments from the Department of Defense 42

Appendix IV: Comments from the Department of Homeland Security 45

Appendix V: Comments from the Office of National Drug Control Policy 47

Table 1: U.S. Counternarcotics Assistance to Countries in the Source and Transit Zones, Fiscal Years 2000-2005

Table 2: Metric Tons of Cocaine Seized and Disrupted in the Transit Zone by Region, Calendar Years 2000-2004

Table 3: Detection and Disruption of Known Actionable Maritime Drug Movements in the Western Caribbean Sea and Eastern Pacific Ocean, Calendar Year 2000 through June 2005

Table 4: ONDCP's Primary Sources of Information on Illicit Drug Availability and Use in the United States

Table 5: Counternarcotics Maritime Law Enforcement Agreements with Countries in the Source and Transit Zones

Figure 1: The Transit Zone

Figure 2: On-Station Ship Days for Interdiction in the Transit Zone, Fiscal Years 2000-2005 
Figure 3: On-Station Flight Hours for Interdiction in the Transit Zone, Fiscal Years 2000-2005

Figure 4: Total P-3 On-Station Flight Hours in the Transit Zone, Fiscal Years 2000-2005

\section{Abbreviations}

$\begin{array}{ll}\text { AWACS } & \text { Airborne Warning and Control System } \\ \text { CBP } & \text { Bureau for Customs and Border Protection } \\ \text { DEA } & \text { Drug Enforcement Administration } \\ \text { DIA } & \text { Defense Intelligence Agency } \\ \text { IACM } & \text { Interagency Assessment of Cocaine Movement } \\ \text { JIATF-South } & \text { Joint Interagency Task Force-South } \\ \text { JIATF-West } & \text { Joint Interagency Task Force-West } \\ \text { ONDCP } & \text { Office of National Drug Control Policy }\end{array}$

This is a work of the U.S. government and is not subject to copyright protection in the United States. It may be reproduced and distributed in its entirety without further permission from GAO. However, because this work may contain copyrighted images or other material, permission from the copyright holder may be necessary if you wish to reproduce this material separately. 
November 15, 2005

The Honorable Charles E. Grassley

Chairman

Caucus on International Narcotics Control

United States Senate

The Honorable Tom Davis

Chairman

Committee on Government Reform

House of Representatives

The Honorable Mark Souder

Chairman

Subcommittee on Criminal Justice, Drug Policy, and Human Resources

Committee on Government Reform

House of Representatives

The 2002 U.S. National Drug Control Strategy set two goals: (1) to lower the rate of illicit drug use by 10 percent over 2 years among both youth and adults and (2) to lower the rate by 25 percent over 5 years in the United States. One of the strategy's three priorities for achieving these goals is to disrupt the illicit drug market in order to reduce the profitability of the drug trade. ${ }^{1}$ To this end, during fiscal years 2000-2005, the United States has provided more than $\$ 6$ billion to Colombia and other countries in the region for counternarcotics, alternative development, and judicial reform efforts. In addition, the United States and certain allies have devoted assets - ships and aircraft - to disrupt the flow of illicit narcotics, primarily cocaine, shipped to the United States through a 6 million square mile area known as the transit zone. ${ }^{2}$

Between calendar years 2001 and 2004, the Office of National Drug Control Policy (ONDCP) reported that cocaine production was reduced by almost

${ }^{1}$ The other two priorities are: (1) stopping illicit drug use before it starts and (2) healing America's drug users.

${ }^{2}$ The transit zone encompasses Central America, Mexico, the Caribbean Sea, the Gulf of Mexico, and the eastern Pacific Ocean. 
one-third and seizures and disruptions ${ }^{3}$ of cocaine in the transit zone increased by over 40 percent to almost 200 metric tons. Despite these reported successes in disrupting cocaine trafficking, a study commissioned by ONDCP indicates that the retail price of cocaine in the United States continued to decline through the second quarter of 2003-the latest available data-while retail purity remained relatively high, indicating that the supply of cocaine had not been reduced. ${ }^{4}$ Further, a 2004 survey on drug use estimated that the number of cocaine users in the United States had remained roughly constant at about 2 million users from 2002 to $2004 .^{5}$ Other sources estimate the number of chronic and occasional cocaine users may be as high as 6 million.

The Joint Interagency Task Force-South (JIATF-South) in Key West, Florida, under the U.S. Southern Command, has primary responsibility for U.S. detection and monitoring of drug trafficking activities in the transit zone. ${ }^{6}$ The Coast Guard has primary operational control for most interdiction operations. The Department of Defense (Defense) provides maritime patrol aircraft, helicopters, and ships; the Department of Homeland Security (Homeland Security) - primarily, the Coast Guard and the Bureau for Customs and Border Protection (CBP $)^{7}$ - provides maritime patrol aircraft, ships, and law enforcement assistance; and the Department of Justice (Justice) provides prosecutorial and law enforcement assistance. JIATF-South also receives some operational support from various countries within the transit zone, and France, the Netherlands, and the United Kingdom also provide air and maritime assistance in the eastern Caribbean Sea.

\footnotetext{
${ }^{3}$ Seizures are defined as taking physical possession of the cocaine. Disruptions are defined as forcing individuals suspected of transporting cocaine to jettison or abandon their cargo.

${ }^{4}$ Rand Corporation, The Price and Purity of Illegal Drugs: 1981 Through the Second Quarter of 2003 (Washington, D.C., November 2004). Specifically, the report uses data compiled through June 2003 and notes that since 2001, the price of cocaine had declined.

${ }^{5}$ Substance Abuse and Mental Health Services Administration, Results from the 2004 National Survey on Drug Use and Health: National Findings (Washington, D.C., September 2005).

${ }^{6}$ Prior to fiscal year 2004, the Joint Interagency Task Force-West, based in Alameda, California, had responsibility for U.S. detection and monitoring activities in the eastern Pacific Ocean. Beginning with fiscal year 2004, JIATF-South was given responsibility for the eastern Pacific Ocean.

${ }^{7}$ On October 31, 2004, Immigration and Customs Enforcement interdiction assets were assigned to CBP. Throughout this report we refer to CBP.
} 
To address your interest in U.S. drug interdiction operations in the transit zone, we examined (1) the changes in the amounts of cocaine seized and disrupted since calendar year 2000 and the factors that have contributed to these changes, (2) trends in the assets provided by the United States and other nations since fiscal year 2000 to support cocaine interdiction in the transit zone, (3) the challenges facing these agencies in maintaining current levels of transit zone interdiction operations, and (4) how the principal agencies involved in interdiction operations assess their performance.

To address these objectives, we focused on cocaine because nearly all the cocaine entering the United States comes from South America through the transit zone. Furthermore, we focused on maritime movements of cocaine through the western Caribbean Sea and the eastern Pacific Ocean because the United States has positioned most of its interdiction assets in these areas. We reviewed relevant planning and resource documents and related reports. We also met with cognizant officials at Defense, Homeland Security, and Justice in Washington, D.C.; law enforcement officers involved in interdiction efforts based in Jacksonville, Miami, Tampa, and Sarasota, Florida, and Nassau, Bahamas; and cognizant officials at JIATFSouth in Key West, Florida. We obtained and analyzed data on (1) cocaine seizures and disruptions for calendar years 2000 through 2004 provided by the U.S. Interdiction Coordinator, and (2) ship days and flight hours spent on interdiction missions during fiscal years 2000-2005, provided by JIATFSouth and JIATF-West. Through comparisons with similar data compiled by the Coast Guard, CBP, and Defense, and discussions with JIATF-South and JIATF-West officials primarily responsible for compiling the data, we determined that these data were sufficiently reliable for the purposes of this report. We performed our work from August 2004 through October 2005 in accordance with generally accepted government auditing standards. (See appendix I for a more complete discussion of our scope and methodology.)

\section{Results in Brief}

Based on data managed by the U.S. Interdiction Coordinator, reported seizures and disruptions of cocaine in the transit zone increased over twothirds from 117 metric tons in calendar year 2000 to a record amount of 196 metric tons in calendar year 2004. Most of the seizures and disruptions occurred in the western Caribbean Sea and eastern Pacific Ocean where the United States has positioned most of its ships and aircraft for interdiction purposes. Overall, according to JIATF-South and other cognizant officials, improved interagency cooperation and intelligence, the use of armed helicopters to assist in interdiction efforts, and improved 
international cooperation contributed to the increased seizures and disruptions. Specifically,

- Through the cooperation of several U.S. law enforcement agencies, specific information about cocaine movements has been provided to JIATF-South. This has permitted JIATF-South to direct operations at more certain targets, rather than searching wide expanses of the transit zone for suspicious movements of boats and small aircraft.

- Beginning in calendar year 2000, the Coast Guard began deploying helicopters equipped with machine guns and 50 caliber sniper rifles to help interdiction efforts, in particular, pursuing and stopping speed boats (called "go-fast" boats) that are a principal mode of transporting cocaine through the transit zone.

- Several nations in the region have increased their cooperation with U.S. efforts to deploy and service aircraft in their countries. For example, the United States has agreements to deploy aircraft in Ecuador, El Salvador, Aruba, and Curacao, and uses facilities in Costa Rica and Panama to support surveillance aircraft, expanding the duration and range of interdiction efforts.

Since fiscal year 2000, the availability of U.S. and allied assets spent on interdiction operations in the transit zone-as measured in on-station ship days and flight hours ${ }^{8}$ - has varied. U.S. and allied on-station ship days decreased from approximately 3,600 days in fiscal year 2000 to about 3,300 in fiscal year 2005, and U.S. and allied on-station flight hours increased from approximately 10,500 hours in fiscal year 2000 to almost 12,900 in fiscal year 2005. However, on-station ship days peaked in fiscal year 2001 and flight hours peaked in fiscal year 2002, but both have generally declined since then, primarily because Defense has provided fewer assets. Declines in Defense assets were largely offset by the Coast Guard, CBP, and several allied European nations-France, the Netherlands, and the United Kingdom. Nevertheless, with the assets available in recent years, JIATFSouth reports that it detected (made visual contact with) less than onethird of the known maritime drug movements.

${ }^{8}$ On-station ship days and on-station flight hours are the time spent on monitoring and interdiction operations. The JIATF-South and JIATF-West figures do not include the time needed for these assets to get in position to begin operations. 
Several challenges raise concerns about the ability of the United States to sustain its level of interdiction operations in the transit zone. Primarily, the availability of some key U.S. assets for interdiction operations, such as maritime patrol aircraft, is declining. Through fiscal year 2005, the number of hours flown by U.S. Navy P-3 maritime patrol aircraft on interdiction missions had decreased nearly 60 percent since fiscal year 2000 (from about 3,560 hours to about 1,490) primarily because of structural problems in the aircraft's wings. In addition, the Netherlands removed its P-3 maritime patrol aircraft from the transit zone in December 2004. According to JIATF-South and other cognizant officials, the declining availability of P-3 maritime patrol aircraft is the most critical challenge to the success of future interdiction operations. Further, the readiness rates for older Coast Guard vessels and maritime patrol aircraft have declined, and the surface radar system used to detect and monitor drug trafficking activities on its aircraft is often inoperable. While some short-term remedies have been taken, cognizant officials expressed concern that the longer-term implications of likely declines in transit zone monitoring and interdiction asset availability have not been addressed. Moreover, officials were concerned that:

- Drug traffickers have changed tactics. In particular, traffickers have taken routes further south and west into the Pacific Ocean before continuing on to Central America or Mexico. This is a much larger area to patrol and makes detection and interdiction more difficult.

- Although most nations in the transit zone, especially countries in Central America and the eastern Caribbean Sea, cooperate with U.S. interdiction efforts, these countries lack the capability and resources to compensate for any decline in U.S. and European allies' assets.

Agencies' performance measures for transit zone interdiction operations vary and data for assessing their performance are problematic. While the Coast Guard has developed performance measures to assess their activities in the transit zone, Defense is currently developing them. CBP has not developed performance measures specifically related to its drug interdiction mission in the transit zone. In our previous work, we noted that the lack of clear measurable goals makes it difficult to link day-to-day efforts to achieving an agency's intended mission. ${ }^{9}$ Additionally, data to

${ }^{9}$ See GAO, Results-Oriented Government: GPRA Has Established a Solid Foundation for Achieving Greater Results, GAO-04-38 (Washington, D.C.: Mar. 10, 2004). 
assess whether operations in the transit zone contribute to the U.S. National Drug Control Strategy's priority of disrupting the illicit drug market or the overall goal of reducing the rate of drug usage in the United States are problematic. For example, ONDCP's annual assessment of cocaine movement for 2004 reported that between 325 to 675 metric tons of cocaine may be moving towards the United States. This wide range is not useful for assessing interdiction efforts. Data on drug availability and use in the United States are difficult to obtain, often cannot be generalized to the entire country, and takes a year or more to collect and analyze. As a result, even under the best of circumstances, several years of drug usage data are needed to show the effects of a change in drug policy. In a 2001 report prepared for ONDCP, the National Research Council concluded that the United States had neither the data systems nor the research infrastructure needed to assess the effectiveness of drug control enforcement policies. In particular, the Council highlighted the absence of adequate, reliable data on illicit drug prices and use. The Council made numerous recommendations to improve data collection and analysis; eight were addressed in full or in part to ONDCP, but ONDCP has not fully addressed the Council's recommendations.

We recommend that the Secretaries of Defense and Homeland Security (1) plan for the likely decline in the future availability of ships and aircraft for transit zone interdiction operations; and (2) develop and coordinate performance measures, in conjunction with ONDCP, that take advantage of available data (such as the number of detections, seizures, and disruptions) to provide a basis for deciding how to deploy increasingly limited assets. We also recommend that the Director of ONDCP address each of the recommendations made by the National Research Council and report to Congress the actions taken, or that still need to be taken, to address them; or document why it should not do so. Overall, in commenting on a draft of this report, Defense, Homeland Security, and ONDCP stated that they generally concurred with the recommendations that applied to them, but did not detail when and how they will address them.

\section{Background}

ONDCP expects that disrupting the illicit drug market will reduce the availability of illicit drugs, increase their cost, and, eventually, reduce the rate of drug usage. To disrupt the cocaine market, the U.S. National Drug Control Strategy calls for, among other things, seizing "enormous and unsustainable" amounts of cocaine from traffickers. One part of the strategy to disrupt the market focuses U.S. interdiction efforts on seizing cocaine and other illicit drugs bound for the United States from South 
America in the transit zone. The transit zone is a six million square mile area that encompasses Central America, Mexico, the Caribbean Sea, the Gulf of Mexico, and the eastern Pacific Ocean (see fig. 1). Typically, drug traffickers use go-fast boats and fishing vessels to smuggle cocaine from Colombia to Central America and Mexico en route to the United States. Gofast boats are capable of traveling over 40 knots and are difficult to detect in open water. Moreover, the go-fast boats often travel at night. When they travel in daylight, the boats are often painted blue, or the crew can cover the boat with a blue tarpaulin, thereby becoming virtually impossible to see. Even when detected, go-fast boats can often outrun conventional ships deployed in the transit zone. 
Figure 1: The Transit Zone

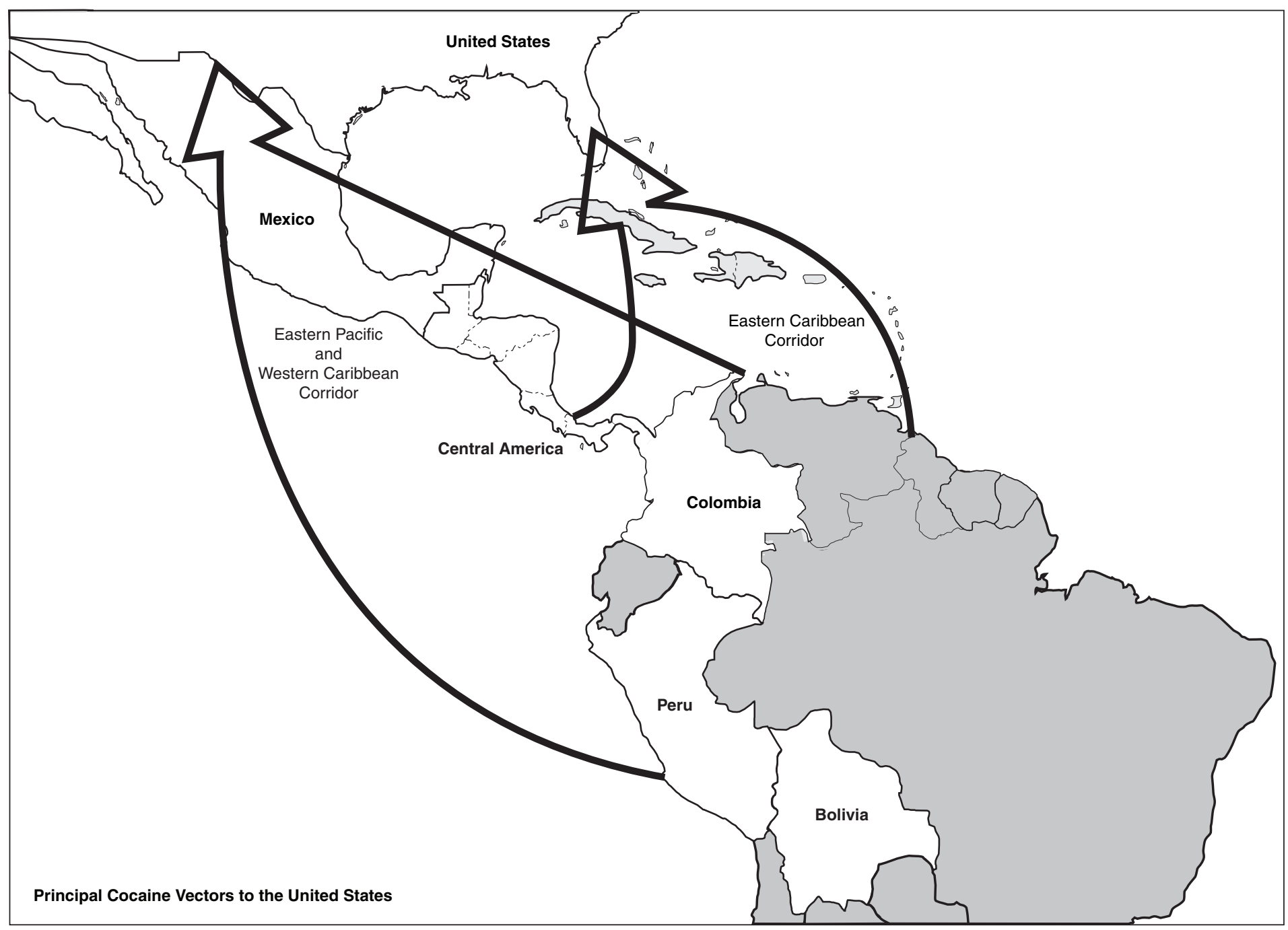

Source: Adapted by GAO based on a similar map in ONDCP's 2004 Interagency Assessment of Cocaine Movement.

The primary departments supporting interdiction operations in the transit zone are Defense, Justice, and Homeland Security. Defense provides surveillance aircraft, helicopters, and maritime vessels; Justice provides prosecutorial and law enforcement assistance; and Homeland Securityprimarily, the Coast Guard and $\mathrm{CBP}$ - provides surveillance aircraft, maritime vessels, and law enforcement assistance. JIATF-South also receives some operational support from various countries in the transit 
zone; and France, the Netherlands, and the United Kingdom provide air and maritime detection and monitoring assistance in the eastern Caribbean Sea. Justice's Drug Enforcement Administration (DEA), Federal Bureau of Investigation, and U.S. Attorney's Office provide intelligence for operations and investigate and prosecute drug traffickers. Other organizations help guide and support interdiction efforts in the transit zone:

- ONDCP oversees and coordinates implementation of the U.S. National Drug Control Strategy and reviews department and agency budget proposals for anti-drug programs, including interdiction efforts in the transit zone.

- The U.S. Interdiction Coordinator reports to the Director, ONDCP, and provides strategic advice and oversight of U.S. agencies' interdiction efforts in the transit zone. It also manages the Consolidated Counterdrug Database that records drug trafficking events, including detections, seizures, and disruptions. The database is vetted quarterly by members of the interagency counterdrug community to minimize duplicate or questionable reported drug movements.

- JIATF-South, under the U.S. Southern Command, is the primary operations center and coordinator for detecting and monitoring suspect air and maritime drug trafficking events in the transit zone. JIATF-South includes representatives from Defense, Justice, Homeland Security, and others; nations such as France, the Netherlands, and the United Kingdom; and several nations in the transit and source ${ }^{10}$ zones.

The Coast Guard, CBP, and Defense do not routinely track funds obligated and expended, ship days, or flight hours provided for drug interdiction in the transit zone. ${ }^{11}$ However, during fiscal years 2000-2005, the United States provided about $\$ 6.2$ billion to support counternarcotics and related programs in the source and transit zones (see table 1).$^{12}$ In the source zone, U.S. assistance supports eradication and interdiction efforts and related

\footnotetext{
${ }^{10}$ The source zone includes the principal drug producing countries of Bolivia, Colombia, and Peru.

${ }^{11}$ See our report titled Drug Control: Difficulties in Measuring Costs and Results of Transit Zone Interdiction Efforts, GAO-02-13 (Washington, D.C.: Jan. 25, 2002).

${ }^{12}$ For fiscal year 2006, the Administration has requested an additional $\$ 735$ million for countries in the source zone and $\$ 77$ million for countries in the transit zone.
} 
programs for alternative development and judicial reform, primarily in Bolivia, Colombia, and Peru. In the transit zone, the United States provided about $\$ 365$ million in assistance-primarily to El Salvador, Guatemala, Haiti, and Mexico - to support interdiction and other law enforcement programs.

Table 1: U.S. Counternarcotics Assistance to Countries in the Source and Transit Zones, Fiscal Years 2000-2005

\begin{tabular}{|c|c|c|c|c|c|c|c|}
\hline \multicolumn{8}{|c|}{ Dollars in millions } \\
\hline \multirow[b]{2}{*}{ Region } & \multicolumn{6}{|c|}{ Fiscal year } & \multirow[b]{2}{*}{ Total } \\
\hline & 2000 & 2001 & 2002 & 2003 & 2004 & $\begin{array}{r}2005 \\
\text { (estimated) }\end{array}$ & \\
\hline Source zone ${ }^{a}$ & $\$ 1,604$ & $\$ 345$ & $\$ 774$ & $\$ 1,123$ & $\$ 964$ & $\$ 1,016$ & $\$ 5,826$ \\
\hline Transit zone & 41 & 41 & 56 & 52 & 92 & 83 & $\overline{365}$ \\
\hline Total & $\$ 1,645$ & $\$ 386$ & $\$ 821$ & $\$ 1,175$ & $\$ 1,056$ & $\$ 1,099$ & $\$ 6,182$ \\
\hline
\end{tabular}

Sources: Congressional Research Service and the State Department.

Note: Totals may not add due to rounding.

aSource zone funding includes the Andean Counterdrug Initiative and related Defense and Foreign Military Financing programs. The table does not include Defense assistance for activities that cannot be directly tied to a nation, such as the operation of ground-based radars.

\section{Several Factors Have Contributed to the Increase in Cocaine Seizures and Disruptions}

Cocaine seizures and disruptions in the transit zone have increased over two-thirds from calendar year 2000 to calendar year 2004. JIATF-South and other cognizant agency officials pointed to a number of factors that contributed to the increases, such as better intelligence on cocaine movements that allow JIATF-South to target specific cocaine shipments; the introduction of armed helicopters increasing the capability to interdict cocaine shipments on go-fast boats; and increased cooperation from nations in the region, which has led to more efficient use of resources.

\section{Cocaine Seizures and Disruptions Have Increased}

Cocaine seizures and disruptions have increased about 68 percent since calendar year 2000. As shown in table 2, the United States and its allies seized or disrupted 157 metric tons of cocaine in calendar year 2003 and 196 metric tons in 2004, a record amount. During this period, about twothirds of all the cocaine seized or disrupted was in the eastern Pacific Ocean and western Caribbean Sea, where according to JIATF-South 
officials, the United States has positioned most of its ships and aircraft for interdiction and other purposes.

Table 2: Metric Tons of Cocaine Seized and Disrupted in the Transit Zone by Region, Calendar Years 2000-2004

\begin{tabular}{lrrrrr}
\hline & \multicolumn{4}{c}{ Calendar year } \\
\cline { 2 - 6 } Region & $\mathbf{2 0 0 0}$ & $\mathbf{2 0 0 1}$ & $\mathbf{2 0 0 2}$ & $\mathbf{2 0 0 3}$ & $\mathbf{2 0 0 4}$ \\
\hline Eastern Pacific Ocean and western Caribbean Sea & 70 & 88 & 92 & 91 & 143 \\
\hline Eastern Caribbean Sea & 14 & 23 & 20 & 26 & 6 \\
\hline Mexico and Central America & 33 & 28 & 26 & 40 & 47 \\
\hline Total for transit zone & $\mathbf{1 1 7}$ & $\mathbf{1 3 9}$ & $\mathbf{1 3 8}$ & $\mathbf{1 5 7}$ & $\mathbf{1 9 6}$ \\
\hline
\end{tabular}

Source: ONDCP's Interagency Assessment of Cocaine Movement based on the Consolidated Counterdrug Database.

\section{Factors Contributing to Increases}

\author{
Better Intelligence
}

Improved intelligence on cocaine shipments gained from law enforcement operations has allowed JIATF-South to more often target suspected drug shipments rather than searching wide expanses of the transit zone for suspicious movements of boats and small aircraft. In addition, in calendar year 2000, the Coast Guard began deploying armed helicopters, which has greatly increased the U.S. capability to stop go-fast boats. Further, several nations in the region have increased their cooperation with U.S. efforts through bilateral maritime agreements, as well as agreements to allow the United States to deploy and re-supply U.S. aircraft and ships on their territory.

An interagency law enforcement investigation operation known as "Panama Express" has increased the amount of intelligence on drug trafficking activities. Panama Express is a multi-agency investigation that was initiated in 1995 and is jointly managed by the Federal Bureau of Investigation, DEA, and Immigration and Customs Enforcement but also includes officials from several federal, ${ }^{13}$ state, and local law enforcement agencies. The U.S. Attorney's Office in Tampa, Florida, provides prosecution support for all Panama Express investigations. According to the U.S. Attorney's office, Panama Express investigations have contributed

\footnotetext{
${ }^{13}$ Other federal law enforcement agencies include the Internal Revenue Service, the Coast Guard, and representatives from JIATF-South.
} 
to the successful prosecution of around 700 individuals, and the seizure and disruption of about 380 metric tons of cocaine since 2000 (or about 51 percent of all the cocaine seized and disrupted).

In addition, a JIATF-South official told us that, as of September 2005, 16 embassies and consulates throughout the region had tactical analysis teams. These teams analyze information on drug trafficking activities and provide the information to JIATF-South, DEA, and other operational organizations for use in interdiction missions.

Armed Helicopters Have Been Added

Increased Cooperation from Nations in the Transit Zone
Interdiction efforts have been strengthened by the addition of armed helicopters. Beginning in calendar year 2000, the Coast Guard began deploying MH-68A helicopters equipped with 7.62 millimeter machine guns and 50 caliber sniper rifles from its base in Jacksonville, Florida. ${ }^{14}$ The helicopters' main value is their capability to pursue and stop go-fast boats, which can travel over 40 knots-often outrunning U.S. and allied surface ships. According to Coast Guard officials, since November 2002 the armed helicopters have successfully stopped every go-fast boat that they have engaged and contributed to 77 maritime drug interdictions and the seizure of approximately 94 metric tons of cocaine.

In addition, the U.S. Navy plans to deploy armed helicopters to pursue and stop go-fast boats in fiscal year 2006. According to Defense officials, these helicopters will have specialized equipment similar to the Coast Guard helicopters. According to the Coast Guard, it will have personnel on board for law enforcement purposes.

Since 2000, the number of countries in the transit zone that have signed all or parts of bilateral maritime agreements increased from 21 to 25 . These agreements permit, among other things, ship boarding rights for U.S. law enforcement officials and pursuit and entry into these countries' territorial waters to interdict drug traffickers. In addition, several countries have agreed to additional provisions in the maritime agreements, in particular, the International Maritime Interdiction Support Clause, which allows the United States to fly suspected drug traffickers detained on U.S. ships directly to the United States for prosecution. As a result, these surface ships can resume patrols in the transit zone rather than transporting the suspects directly to the United States, or waiting in a foreign port for the

\footnotetext{
${ }^{14}$ Also beginning in calendar year 2000, the Coast Guard began deploying "over the horizon boats" capable of pursuing go-fast boats.
} 
suspects to be extradited. Coast Guard officials told us that, in many cases, this saves up to a week of ship time. (See app. II for a list of countries that have signed all or parts of the bilateral maritime agreements and the interdiction support clause.)

Moreover, to offset the closing of Howard Air Force Base in Panama in 1999, the United States has reached agreements with other nations in the region to station U.S. military and civilian aircraft. In return, the United States has upgraded the facilities at these airbases. The facilities at Manta, Ecuador; Comalapa, El Salvador; and Curacao are used by U.S. civilian and military aircraft, while the facilities in Aruba; Liberia; Costa Rica; and Panama are used by the Coast Guard and CBP. Access to these facilities allows aircraft to spend more time monitoring and interdicting drug trafficking activities and also allows them to range further west into the Pacific Ocean.

\section{Availability of Assets Provided for Interdiction Operations Have Varied Since Fiscal Year 2000}

Overall, since fiscal year 2000, the availability of U.S. and allied assets provided for detecting and disrupting drug trafficking activities in the transit zone has varied. On-station ship days peaked in fiscal year 2001 and flight hours peaked in fiscal year 2002, but both have declined since then, primarily because Defense has provided fewer assets. Declines in Defense assets in recent years were mostly offset by additional ship days and aircraft hours provided by the Coast Guard, CBP, and allied nations. However, the ship days and flight hours provided by the allied nations are primarily in the eastern Caribbean Sea where the United States does not usually conduct monitoring and detection activities. Nevertheless, according to JIATF-South, it cannot detect many of the known maritime cocaine movements reported in the western Caribbean Sea and the eastern Pacific Ocean because it cannot get ships or aircraft to the suspected movement in time.

\section{On-Station Ship Days Generally Declined}

Despite a rise in fiscal year 2001, the total number of ship days spent on interdiction missions in the transit zone has generally decreased since fiscal year $2000^{15}$ from about 3,600 ship days to about 3,300 ship days (or

\footnotetext{
${ }^{15}$ On-station ship days for the eastern Pacific Ocean for the first quarter of fiscal year 2000 (September-December 1999) were not readily available. In fiscal year 2001, JIATF-West first quarter on-station ship days was about 5.4 percent of the year's total.
} 
about 8 percent) in fiscal year 2005. U.S. Navy ship days declined from about 1,980 in fiscal year 2000 to about 890 in fiscal year 2005. Defense officials said that the Navy reduced its ship days because of other national security concerns; in particular, the need to provide support for the armed conflicts in Afghanistan and Iraq.

The reduction in U.S. Navy ship days was partly offset by increases in ship days by the Coast Guard. After a decline to about 1,160 ship days in fiscal year 2003 (compared to 1,330 days in 2002), the Coast Guard increased its ship days to about 1,660 in 2004 and almost 1,700 in 2005-becoming the primary provider of maritime surface vessels in the transit zone. Figure 2 illustrates the total on-station ship days in the transit zone by provider for fiscal years 2000-2005.

Figure 2: On-Station Ship Days for Interdiction in the Transit Zone, Fiscal Years 2000-2005

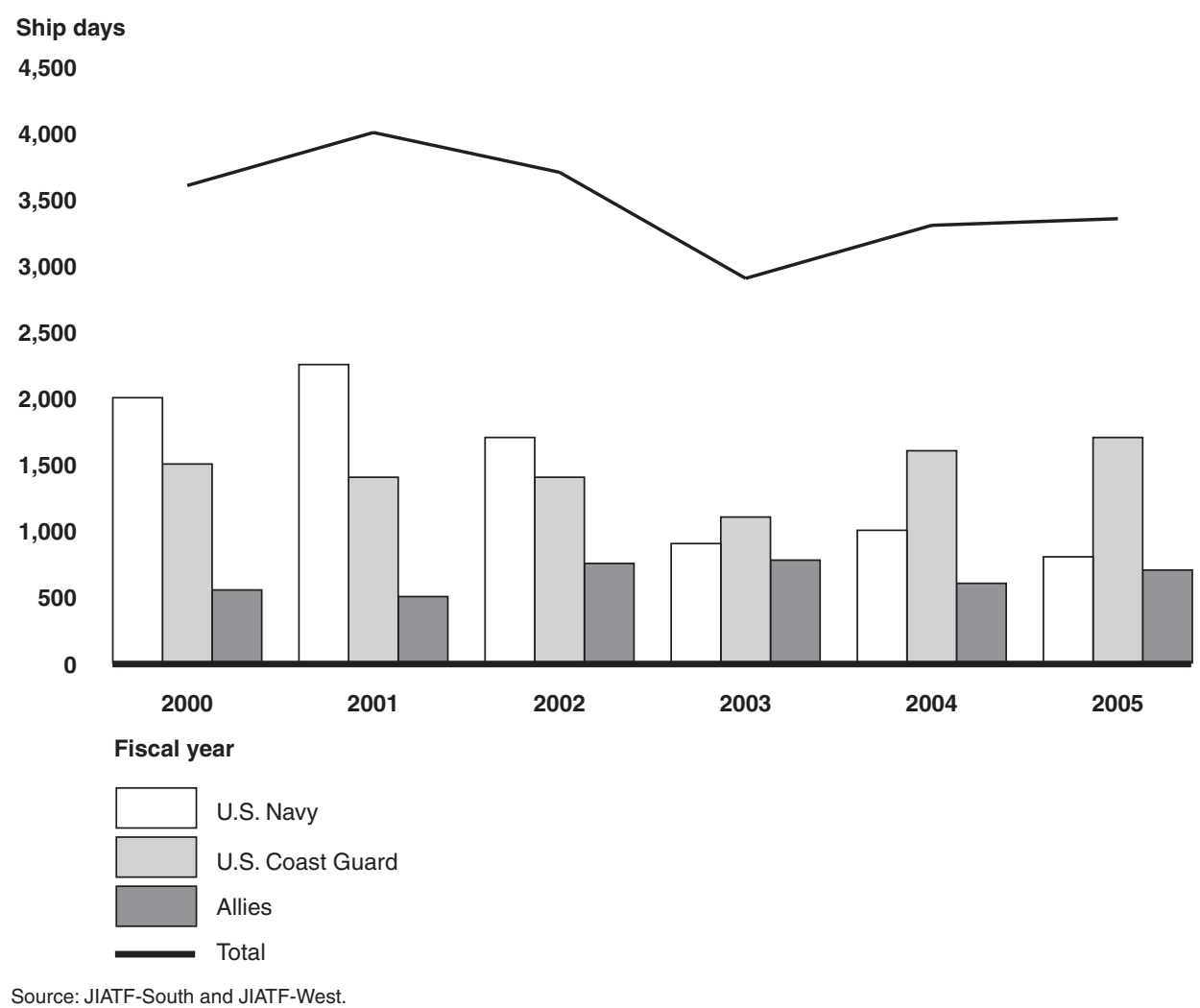




\section{On-Station Flight Hours Generally Declined in Recent Years}

On-station flight hours for counternarcotics activities in the transit zone increased about 35 percent between fiscal years 2000-2002-from about 10,500 hours to about 14,200-but have generally declined since then to about 12,870 hours in 2005 . Declines in the availability of Defense maritime patrol aircraft over the period were offset by increased support from the Coast Guard, CBP, and several allied nations_-France, the Netherlands, and the United Kingdom.

- The Coast Guard's on-station flight hours in the transit zone decreased from about 2,440 in fiscal year 2000 to less than 1,300 hours in fiscal year 2002. According to Coast Guard officials, the decline was due, in part, to resources being diverted to other Coast Guard missions. But the Coast Guard has since increased its flight hours to over 2,780 hours in fiscal year 2005 .

- $\mathrm{CBP}$ has increased its on-station flight hours for interdiction operations in the transit zone since fiscal year 2000-from about 180 hours in fiscal year 2000 to nearly 4,385 hours in fiscal year 2005 . However, in fiscal year 2003, its flight hours declined to about 2,040 due to the diversion of resources for other homeland security missions.

- Defense on-station flight hours for interdiction in the transit zone gradually declined from about 6,860 in fiscal year 2000 to 6,500 in fiscal year 2002, but declined more rapidly since then to about 2,940 flight hours in fiscal year 2005. JIATF-South officials attribute the recent declines primarily to the reduced availability of U.S. Navy P-3 maritime patrol aircraft because of structural problems. In addition, U.S. Air Force Airborne Warning and Control System (AWACS) aircraft were diverted to support homeland security missions and the armed conflicts in Afghanistan and Iraq. ${ }^{16}$

- Allied nations steadily increased their flight hours in support of interdiction operations from about 1,000 hours in fiscal year 2000 to 4,070 hours in fiscal year 2004. However, in fiscal year 2005, the allies' total hours declined to about 2,760. According to JIATF-South and U.S. Interdiction Coordinator officials, most of the allies' surveillance

\footnotetext{
${ }^{16}$ An AWACS aircraft resumed operations in the transit zone in November 2004 and a second AWACS aircraft was added in April 2005.
} 
operations are in the eastern Caribbean Sea where the United States does not usually conduct interdiction operations.

Figure 3 illustrates the total on-station flight hours by provider for fiscal years 2000-2005.

Figure 3: On-Station Flight Hours for Interdiction in the Transit Zone, Fiscal Years 2000-2005

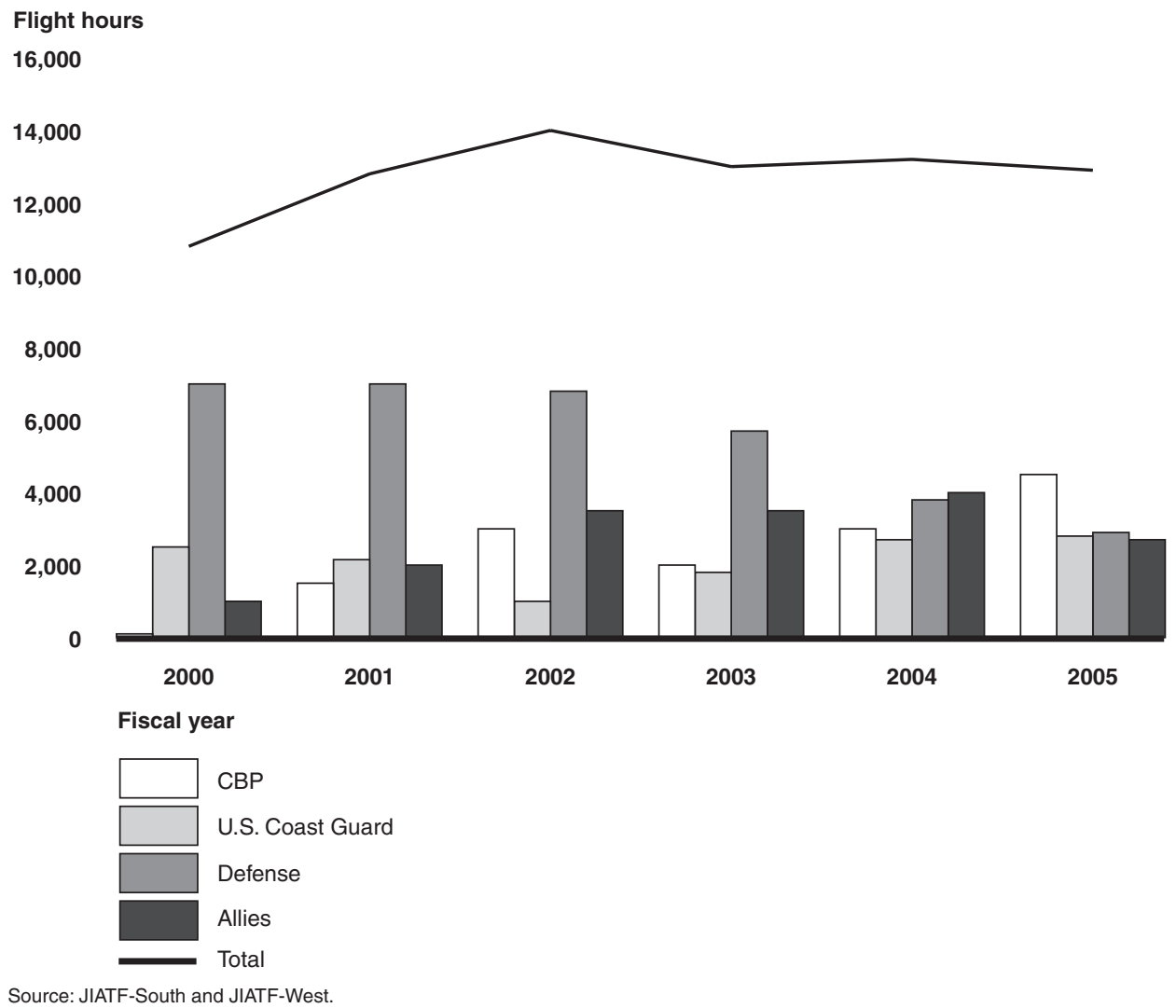

Increasing Number of Known Actionable Maritime Events Challenges JIATFSouth's Detection Capability
Since calendar year 2000, JIATF-South officials report that they had information about more maritime drug movements than they could detect 
(make visual contact with). The number of "known actionable" 17 maritime events in the western Caribbean Sea and the eastern Pacific Ocean more than doubled from 154 in 2000 to 330 in 2004. According to JIATF-South officials, in many cases, the maritime event is too far away for available ships and aircraft to go to the area and visually locate the suspected drug movement. However, once JIATF-South locates a suspect movement, the disruption rate has significantly increased since 2000-from less than 60 percent in 2000 and 2001 to over 80 percent in 2003 to 2005 (see table 3).

Table 3: Detection and Disruption of Known Actionable Maritime Drug Movements in the Western Caribbean Sea and Eastern Pacific Ocean, Calendar Year 2000 through June 2005

\begin{tabular}{|c|c|c|c|c|c|c|c|}
\hline & \multicolumn{6}{|c|}{ Calendar years } & \multirow[b]{2}{*}{ Tota } \\
\hline & 2000 & 2001 & 2002 & 2003 & 2004 & $\begin{array}{r}2005 \text { (through } \\
\text { June 2005) }\end{array}$ & \\
\hline Known actionable maritime events & 154 & 160 & 178 & 253 & 330 & 184 & 1,259 \\
\hline Detections & 59 & 56 & 77 & 65 & 92 & 48 & 397 \\
\hline Seizures and disruptions & 35 & 30 & 53 & 55 & 80 & 39 & 292 \\
\hline Percentage of known events detected & 38 & 35 & 43 & 26 & 28 & 26 & 31.5 \\
\hline $\begin{array}{l}\text { Percentage of detected events } \\
\text { disrupted }\end{array}$ & 59 & 54 & 69 & 85 & 87 & 81 & 73.6 \\
\hline
\end{tabular}

Source: JIATF-South based on the Consolidated Counterdrug Database.

Note: The Consolidated Counterdrug Database is managed by the U.S. Interdiction Coordinator's office. Beginning with 2004, the Coordinator's office began implementing stricter rules in vetting the data on drug movements, detections, and seizures and disruptions in quarterly meetings with the interagency drug community. The intent was to minimize potential duplication and the counting of events that may not have occurred. According to the database manager, however, the more careful review of the data did not materially affect the number of maritime drug movements counted. The primary differences were in the number of suspect aircraft flights.

\section{Challenges in Maintaining Interdiction Operations}

While the United States has increased the number of seizures and disruptions in the transit zone since 2000, the Coast Guard, CBP, and Defense face several challenges in maintaining the current level of assets provided for transit zone interdiction operations. JIATF-South officials

\footnotetext{
17"Known actionable" events include events that are confirmed through a seizure of some or all of the drugs, were deemed "actionable" by the Navy or Coast Guard (within their capability to seize or disrupt), or could not be reasonably attributed to anything other than drug trafficking (for example, jettisoning cargo or scuttling a vessel when detected by law enforcement officials).
} 
expressed concern that continued declines in U.S. on-station ship days and on-station flight hours will limit their ability to monitor the transit zone and detect illicit drug trafficking. Specifically, according to JIATF-South and other Defense officials, the reduced availability of the U.S. Navy P-3 maritime patrol aircraft will degrade JIATF-South's ability to detect maritime movements. In addition, the readiness rates of older Coast Guard ships, which support interdiction operations in the transit zone, have declined since fiscal year 2000, and the surface radar system on its longrange surveillance aircraft is often inoperable. JIATF-South, Coast Guard, CBP, and U.S. Interdiction Coordinator officials stated that, while some short-term fixes have been made, the longer-term implications of the likely continued declines in monitoring and interdiction assets for the transit zone have not been addressed.

Moreover, in response to increases in cocaine seizures and disruptions, drug traffickers have adjusted their tactics for transporting cocaine through the transit zone. Finally, nations in the region lack the resources to offset any decline in assets.

\section{Declining Availability of P-3} Aircraft Will Degrade JIATFSouth's Maritime Detection Capability
According to cognizant officials with JIATF-South and U.S. Interdiction

Coordinator officials, compensating for the reduced availability of P-3 maritime patrol aircraft is the most critical challenge to the future success of interdiction operations. According to these officials, because of its longer range, the P-3 aircraft can monitor a much larger surface area than other maritime patrol aircraft and can provide covert surveillance until other assets arrive.

The availability of the P-3 aircraft has declined for several reasons. In fiscal years 2000-2003, the U.S. Navy provided the majority of P-3 maritime patrol flying hours in support of interdiction efforts-about 60 percent of the onstation flight hours (or over 3,900 hours per year). However, in fiscal year 2004, the Navy began limiting the use of its P-3 maritime patrol aircraft for transit zone interdiction missions because of structural problems in its wings ${ }^{18}$ and other worldwide commitments. Since fiscal year 2000, the number of hours flown by U.S. Navy P-3s has decreased nearly 60 percent to about 1,500 hours in fiscal year 2005. In addition, in December 2004, the

\footnotetext{
${ }^{18}$ The P-3 is a 40-year-old aircraft and has begun to develop cracks in its wing structure. Currently, the Navy plans to retire the P-3 and replace it with a different aircraft. However, the full fleet of aircraft will not be available until 2013.
} 
Netherlands removed the P-3 aircraft it used to fly interdiction missions in the transit zone. According to the U.S. Interdiction Coordinator, the P-3s flown by the Netherlands were vital to interdiction efforts in the Caribbean Sea, averaging over 1,300 flight hours per year-or about 20 percent of all P-3 flight hours-during fiscal years 2000-2004. In April 2005, the Netherlands began using the Fokker F-60, a shorter-range twin engine aircraft, to fly interdiction missions; but, according to Defense officials, these aircraft are less capable than the P-3.

To help compensate for the reduction in the P-3 availability, CBP has increased its P-3 maritime patrol on-station flight hours in the transit zone-from about 180 flight hours in fiscal year 2000 to over 4,300 hours in 2005. However, CBP officials told us that their aircraft cannot totally compensate for the loss of the Navy's and Netherlands' P-3 flying hours. Further, these officials are unsure how long CBP will be able to continue to provide the additional flying hours, which has been more than its allotted budget, because of other homeland security priorities.

Figure 4 illustrates the recent decline in P-3 flight hours. 


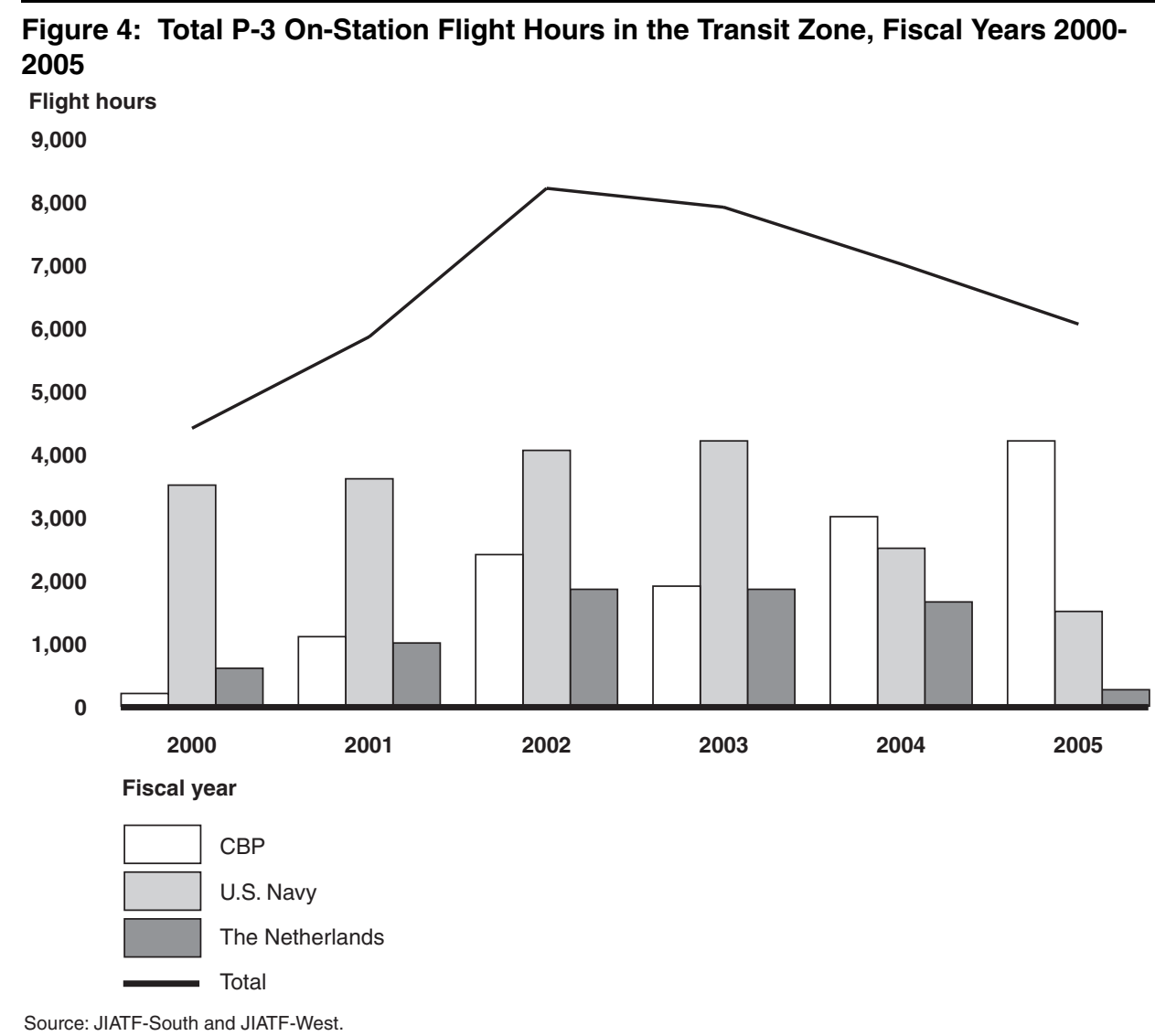

In August 2004, the U.S. Interdiction Coordinator established a working group to evaluate the problem of the reduction in maritime patrol aircraft flying hours and identify possible solutions. The group identified several possible alternatives, including:

- redeploying AWACS to support an aerial interdiction program in Colombia,

- substituting other Defense aircraft for the Navy P-3s,

- extending the amount of time aircraft are deployed to forward operating locations throughout the region,

- increasing the number of hours flown by the Coast Guard HC-130 surveillance aircraft in support of interdiction, 
- upgrading the sensors on existing aircraft to improve their capabilities,

- deploying aircraft to locations closer to the suspected trafficking routes, and

- requesting additional funding to support the deployment of United Kingdom maritime patrol aircraft in the transit zone.

According to JIATF-South officials, several of these proposals have been implemented. AWACS have begun flying missions in support of the aerial interdiction program in Colombia (also known as the "Air Bridge Denial" program $)^{19}$-relieving CBP of much of this burden. The Coast Guard and CBP have deployed aircraft to locations in Costa Rica and Ecuador, and the Coast Guard has received funding to upgrade some of its detection and monitoring equipment with improved sensors. Finally, Defense is providing housing for United Kingdom aircrews (relieving them of the financial burden) that provide surveillance in the Caribbean Sea while flying training missions. But, JIATF-South, the U.S. Interdiction Coordinator, and other cognizant officials noted that the longer term prospect of further declines in U.S. P-3 or other maritime patrol assets for interdiction operations has not been addressed.

Readiness Rates for Aging Coast Guard Ships and Aircraft Have Declined
During fiscal years 2000 through 2004, the readiness rates of the Coast Guard's older ships and aircraft showed a general decline, although the rates fluctuated from year to year. ${ }^{20}$ For example, ships used to monitor drug trafficking activities and carry the helicopters that disable and stop go-fast boats were below their target levels for time free of major deficiencies or loss of at least one primary mission. Further, the percentage of time that HC-130 surveillance aircraft were available to perform missions was below the target level in fiscal year 2004, and the surface radar system on the aircraft is subject to frequent failures. In some instances, mission flight crews had to look out the windows of the aircraft for targets because the radar systems were inoperable.

\footnotetext{
${ }^{19}$ For more information about this program, see our report titled Drug Control: Air Bridge Denial Program in Colombia Has Implemented New Safeguards, but Its Effect on Drug Trafficking Is Not Clear, GAO-05-970 (Washington, D.C.: Sept. 6, 2005).

${ }^{20}$ The Coast Guard uses these assets to perform a variety of missions, such as interdicting illicit drug shipments or attempted landings by illegal aliens and rescuing mariners at sea.
} 
The Coast Guard has taken several actions to keep its assets operational. These include establishing a compendium of information for making decisions regarding maintenance and upgrades; performing more extensive maintenance between deployments; and exploring strategies for prioritizing the maintenance and capability enhancement projects needed to provide more objective data on where to spend budget dollars and enhance mission capabilities. However, these additional efforts, while helpful in preventing a more rapid decline in the condition of existing assets, are unlikely to solve the problem. For fiscal year 2004, the Coast Guard's estimated cost of deferred maintenance for these assets totaled approximately $\$ 28$ million. $^{21}$

\section{Drug Traffickers Have Changed Tactics}

Interdiction operations are further challenged by the changing tactics of the drug traffickers. In the eastern Pacific Ocean, JIATF-South in recent years has detected suspect fishing vessels and go-fast boats traveling further south and about 300 miles southwest of the Galapagos Islands before turning towards Central America and Mexico. This change in tactics has greatly increased the ocean surface area that must be monitored and, because of the distances to travel, has made it more difficult for U.S. surface ships and aircraft to respond to suspected cocaine movements. In addition:

- Drug traffickers have begun using larger go-fast boats. In the past, gofast boats typically transported 2 to 4 metric tons of cocaine, but some are now capable of carrying up to 8 metric tons.

- Drug traffickers in the eastern Pacific Ocean have increasingly used vessels registered to countries, such as Ecuador and Mexico, with which the United States has no maritime boarding agreements. The use of these vessels complicates the process of boarding and searching for illicit drugs.

Moreover, Ecuador has declared that its territorial waters extend 200 miles from its coastline and around the Galapagos Islands (most nations,

\footnotetext{
${ }^{21}$ For more information about the condition of Coast Guard ships and aircraft, see Coast Guard: Preliminary Observations on the Condition of Deepwater Legacy Assets and Acquisition Management Challenges, GAO-05-651T (Washington, D.C.: June 21, 2005) and Coast Guard: Preliminary Observations on the Condition of Deepwater Legacy Assets and Acquisition Management Challenges, GAO-05-307T (Washington, D.C.: Apr. 20, 2005).
} 
including the United States set a 12-mile territorial limit). Although the United States does not recognize Ecuador's claim, U.S. ships and aircraft generally do not enter this area for interdiction missions to avoid the potentially politically sensitive issue of having to deal with the Government of Ecuador.

\section{Capability of Nations in the Transit Zone to Assist with Interdiction Is Limited}

Although most nations in the transit zone-especially countries in Central America and the eastern Caribbean Sea-cooperate with U.S. interdiction efforts, JIATF-South and other officials told us that these countries lack the capability and resources to compensate for any decline in U.S. and allies' assets. Most countries in the transit zone are able to provide only a few vessels or aircraft to intercept drug traffickers or lack secure communications equipment needed to coordinate with U.S. law enforcement counterparts during interdiction missions. Also, many of these countries do not have a civilian law enforcement or military presence in the coastal areas where drug traffickers work with local criminal organizations to offload cocaine shipments and deliver them to the United States. In addition, U.S. agencies are reluctant to work with law enforcement officials in some countries because of widespread corruption.

From fiscal year 2000 through 2005, the United States provided about $\$ 365$ million in assistance to countries in the transit zone. Of this, Mexico received approximately $\$ 115$ million to support its efforts to eradicate opium poppy and marijuana, and improve surveillance and intelligence capabilities. The transit zone countries in Central America and the Caribbean received the remainder, with most of this assistance for programs to assist civilian law enforcement and military agencies in El Salvador, Guatemala, Jamaica, and Panama.

Assistance provided to transit zone countries in Central America and the Caribbean from State's Bureau for International Narcotics and Law Enforcement Affairs increased from approximately $\$ 18$ million in fiscal year 2000 to about $\$ 25$ million in fiscal year 2002 but has since declined to about $\$ 7$ million in fiscal year 2005 . A State official attributed the decline in assistance to commitments in Afghanistan and Iraq. State assistance has been used for helicopter airlift support to Guatemala's police counternarcotics units and interceptor boats for the Bahamas, among other things.

Assistance for transit zone countries in Central America and the Caribbean provided through the Foreign Military Finance and International Military 
Education and Training programs has increased from about $\$ 19$ million in fiscal year 2000 to about $\$ 36$ million in fiscal year 2005 . This assistance has been used to train host country personnel and provide equipment such as helicopters, spare parts, and fuel to support counternarcotics training and missions.

Agencies' Performance
Measures Vary and
Data for Assessing
Performance Are
Problematic

Agencies' Performance Measures Vary and Data for Assessing Problematic
The Government Performance and Results Act of 1993 requires federal agencies to develop performance measures to assess progress in achieving their goals, and to communicate their results to the Congress. ${ }^{22}$ The act requires agencies to set multiyear strategic goals in their strategic plans and corresponding annual goals in their performance plans, measure performance toward the achievement of those goals, and report on their progress in their annual performance reports. These reports are intended to provide important information to agency managers, policymakers, and the public on what each agency accomplished with the resources it was given. Moreover, the act calls for agencies to develop performance goals that are objective, quantifiable, and measurable, and to establish performance measures that adequately indicate progress toward achieving those goals. Our previous work has noted that the lack of clear measurable goals makes it difficult for program managers and staff to link their day-today efforts to achieving the agency's intended mission. ${ }^{23}$

When multiple agencies are involved in achieving the desired results, as with transit zone interdiction operations, agencies should coordinate the development of performance measures to ensure that they are complementary. In the case of the transit zone, performance measures and approaches for assessing transit zone operations vary among the Coast Guard, CBP, and Defense. In addition, basic information about cocaine production and trafficking and cocaine usage in the United States that would help in assessing transit zone interdiction operations is problematic. Further, ONDCP and other agencies involved have not fully addressed recommendations for improving illicit drug data collection and analysis.

\footnotetext{
${ }^{22}$ Pub. L. 103-62, as amended.

${ }^{23}$ GAO-04-38.
} 


\section{Transit Zone Performance} Measures Vary
According to the 2005 U.S. National Drug Control Strategy update, the 2002 U.S. National Drug Control Strategy "clearly laid out a plan for accountable results in achieving a single goal—reducing drug use." Yet specific measures of performance in the transit zone linking interdiction operations to the Strategy's priority of disrupting the illicit drug market were not included in the 2002 strategy, nor subsequently developed across the agencies in conjunction with ONDCP. The performance measures developed by the Coast Guard, and the measures being developed by CBP and Defense, vary in their emphasis and may not be helpful in assessing progress in disrupting the illicit drug market.

- The Coast Guard's performance measures related to the transit zone set specific goals to reduce the flow of cocaine. For fiscal year 2004, the goal was to remove 15 percent of the cocaine flowing through the transit zone; according to Coast Guard officials, the removal goal increases to 35 percent in 2011.

- $\mathrm{CBP}$ is developing performance measures related to operational readiness rates (a measure of its ability to respond when requested), but these rates are not specific to the transit zone or to counternarcotics activities and do not measure results.

- Defense is developing performance measures that focus on the number of disruptions of cocaine trafficking events, but it has not yet set any targets or goals to assess its progress.

\section{Data for Assessing Transit Zone Interdiction Operations and Drug Use in the United States Are Problematic}

Data for assessing U.S. interdiction operations in the transit zone and relating the results to the U.S. National Drug Control Strategy's priority of disrupting the illicit drug market and to its overall goal of reducing drug usage in the United States are problematic. Specifically, the data for estimating the cocaine flowing through the transit zone towards the United States has been called into question, and data to demonstrate progress in reducing drug use are difficult to obtain in ways that can be generalized to the United States.

The principal source of information about cocaine flow in the transit zone is ONDCP's Interagency Assessment of Cocaine Movement (IACM). The IACM is prepared annually for ONDCP by an interagency group representing departments and agencies involved in U.S. counternarcotics 
efforts. ${ }^{24}$ The assessment is intended to advise policymakers and resource planners whose responsibilities involve detecting, monitoring, and interdicting illicit drug shipments. It draws on other studies and several datasets to estimate cocaine supply (that is, how much cocaine is produced and available for export to the United States) and demand (that is, how much cocaine is used in the United States and elsewhere). In the past, the IACM's estimates of cocaine supply were close to the estimated demand in the United States and other world markets plus estimated losses in transit, source, and arrival zones. But for calendar years 2003 and 2004, according to the interagency group, the IACM's estimate of the amount of cocaine available for export was too low in relation to estimated U.S. and non-U.S. demand for cocaine after taking into account seizures and disruptions.

The interagency assessment noted that the increasing difference between supply and demand estimates may be the result of several different scenarios, a combination of which points to potential shortfalls in some or many of the data sets. For example:

- Production and consumption estimates could be widely off the mark. Production estimates are not designed to capture dynamic activities such as eradication, replanting, or changing processing efficiencies.

- Worldwide consumption estimates are several years old (for example, the U.S. estimate was developed in 2002) and may not yet show the effects of record eradication and interdiction efforts in recent years.

- Time lags in estimating aspects inherent to the cocaine trade-including price, purity, and demand-could delay the apparent effects and documentation of a shortage.

As a result of the disparity between the estimated cocaine supply and demand, the interagency group stated that a precise estimate of cocaine flow was not possible for 2004, and that "a range of possible amounts was more intellectually and analytically honest." The group estimated that between 325 and 675 metric tons of cocaine flowed towards the United

\footnotetext{
${ }^{24}$ The interagency group is headed by the Defense Intelligence Agency and includes the U.S. Director of Central Intelligence, Crime and Narcotics Center; the Coast Guard; CBP; DEA; JIATF-South; JIATF-West; the National Security Agency; the Office of Naval Intelligence; State; and the U.S. Southern Command. In addition, Her Majesty's Customs and Excise (United Kingdom) participates.
} 
States in 2004, but such a wide range is not useful for assessing transit zone interdiction efforts.

ONDCP and other interagency group officials agreed that the wide range reflects the difficulty in obtaining specific information about the production of cocaine and how it gets to the United States. According to ONDCP, the Director of ONDCP has established a working group to identify and, where possible, quantify the uncertainties with the IACM, and identify ways to improve the data and reduce uncertainty.

Tracking Illicit Drug Use in the United States Is Difficult
ONDCP uses several surveys and databases to help it assess the availability and rate of illicit drug use in the United States and changes in those measures over time, but a variety of issues affect their reliability and validity. According to several studies and ONDCP officials, a large portion of major cocaine (and other drug) users are members of generally hard-tosurvey populations, such as the homeless or incarcerated, and those who are questioned about illicit drug use may be inclined to provide a socially acceptable, and legal, response to survey questions. In addition, typical survey response problems, such as low response rates and failure of respondents to accurately recall past events, also apply.

Moreover, according to ONDCP officials, obtaining information from and about persons engaged in an illegal activity is difficult at best, much of the available information about illicit drug use cannot be generalized to the United States, and the logistics of collecting meaningful data means that a time lag will always exist between the data collection period and the time when the data are available for public policy purposes. Thus, under the best of circumstances, the effect of a drug policy change may take a number of years to demonstrate.

Table 4 lists the primary sources of information ONDCP uses to track illicit drug trends in the United States and highlights the latest date of data collection, ONDCP's primary purpose, and selected issues about the information source. In some cases, the survey or database was designed for other purposes and ONDCP officials have adapted it for their use. 
Table 4: ONDCP's Primary Sources of Information on Illicit Drug Availability and Use in the United States

\begin{tabular}{|c|c|c|c|}
\hline Data source & $\begin{array}{l}\text { End of most } \\
\text { recent data } \\
\text { collection }\end{array}$ & ONDCP's primary purpose & Selected issues \\
\hline $\begin{array}{l}\text { System to Retrieve } \\
\text { Information from Drug } \\
\text { Evidence (STRIDE) }\end{array}$ & June 2003 & $\begin{array}{l}\text { Assess price and purity of } \\
\text { cocaine in the United States. }\end{array}$ & $\begin{array}{l}\text { - Data cannot be generalized to the United States. } \\
\text { - Designed as an inventory system for drugs turned } \\
\text { into DEA by its agents and informants and other } \\
\text { law enforcement agencies. } \\
\text { - Trends could reflect law enforcement patterns } \\
\text { rather than drug availability patterns. }\end{array}$ \\
\hline $\begin{array}{l}\text { Drug Abuse Warning } \\
\text { Network (DAWN) }\end{array}$ & December 2003 & $\begin{array}{l}\text { Assess drug-related hospital } \\
\text { emergency department visits } \\
\text { and deaths investigated by } \\
\text { medical examiners and } \\
\text { coroners. }\end{array}$ & $\begin{array}{l}\text { - Data cannot be generalized to the United States. } \\
\text { - Intended to identify new drug trends, not drug } \\
\text { consumption. } \\
\text { - Coverage depends on emergency departments } \\
\text { and medical examiners identifying and reporting } \\
\text { drug-related incidents. }\end{array}$ \\
\hline $\begin{array}{l}\text { Arrestee Drug Abuse } \\
\text { Monitoring } \\
\text { (ADAM) }\end{array}$ & March 2004 & $\begin{array}{l}\text { Assess drug and alcohol use } \\
\text { among arrestees in } 39 \text { cities } \\
\text { and counties. This population } \\
\text { is typically composed of hard- } \\
\text { core drug users. }\end{array}$ & $\begin{array}{l}\text { - Data cannot be generalized to the United States. } \\
\text { - Cancelled in January 2004. ONDCP is attempting } \\
\text { to restore funding for fiscal year 2006, but a new } \\
\text { survey cannot be completed until 2008. }\end{array}$ \\
\hline Monitoring the Future (MTF) & December 2004 & $\begin{array}{l}\text { Track drug use rates among } \\
8^{\text {th }}, 10^{\text {th }}, \text { and } 12^{\text {th }} \text { grade } \\
\text { students; college students; } \\
\text { and young adults. }\end{array}$ & $\begin{array}{l}\text { - Survey does not include school dropouts and } \\
\text { absentees, or others who may be institutionalized. } \\
\text { - Relies on self-reporting. }\end{array}$ \\
\hline $\begin{array}{l}\text { National Survey on Drug Use } \\
\text { and Health (NSDUH) }\end{array}$ & December 2004 & $\begin{array}{l}\text { Track incidence and } \\
\text { prevalence of substance } \\
\text { abuse in the general } \\
\text { population by surveying } \\
\text { individuals over } 12 \text { years old } \\
\text { living in households. }\end{array}$ & $\begin{array}{l}\text { - The survey generally does not cover hard-core } \\
\text { drug users because it excludes homeless persons } \\
\text { not in shelters and individuals in jails, detention } \\
\text { centers, and drug treatment centers. } \\
\text { - Relies on self-reporting. }\end{array}$ \\
\hline
\end{tabular}

Source: GAO analysis of data sources.

\section{ONDCP Has Not Fully Addressed Prior Recommendations for Improving Drug Data Collection and Analysis}

In a 2001 report prepared for ONDCP, the National Research Council concluded that the United States had neither the data systems nor the research infrastructure needed to assess the effectiveness of drug control enforcement policies. ${ }^{25}$ In particular, the Council highlighted the absence of adequate, reliable data on illicit drug prices and use. The Council made numerous recommendations to improve data collection and analysis-

\footnotetext{
${ }^{25}$ National Research Council, Informing America's Policy on Illegal Drugs: What We Don't Know Keeps Hurting Us (Washington, D.C.: 2001).
} 
eight were addressed in full or in part to ONDCP. Regarding interdiction, the Council recommended that research be done to address the following:

- to what extent traffickers can limit the effect of interdiction operations by shifting their routes and modes of transportation;

- how the deterrent effects of supply-reduction programs can be measured and the size of these effects; and

- how quickly drug production and trafficking adapt to supply-reduction activities, what happens to supply and price during the period of adaptation, and how long the deterrent effects of supply-reduction operations last before new supply sources emerge.

ONDCP officials told us these recommendations have not been fully addressed. They noted that the illicit and secretive nature of the illicit drug market precludes the systematic collection of cultivation, production, and trafficking information. Furthermore, these officials emphasized that the economics of cocaine production and trafficking may not follow typical supply and demand relationships_-profit margins likely remain high despite record coca eradiation and cocaine interdiction efforts, and drug traffickers can quickly react to changing interdiction tactics and circumstances.

\section{Conclusions}

Since fiscal year 2000, the United States has provided over $\$ 6$ billion for counternarcotics and related programs in South and Central America and throughout the transit zone, primarily to reduce the amount of illicit drugs produced and transported to the United States. While the number of onstation ship days and on-station flight hours provided for monitoring and interdiction operations in the transit zone has varied since 2000, they have generally declined in recent years. JIATF-South, Coast Guard, and CBP officials are concerned that the current level of operations cannot be sustained. Defense on-station ship days and flight hours have already declined due to operational priorities in other parts of the world, primarily Afghanistan and Iraq, and structural limitations on the U.S. Navy's primary maritime patrol aircraft— the P-3. The reduced availability of P-3 maritime patrol aircraft will degrade JIATF-South's ability to detect and monitor gofast boats and other vessels suspected of transporting illicit drugs. JIATFSouth, Coast Guard, and CBP officials are concerned that this problem is likely to worsen as budget constraints and other homeland security priorities arise that limit the assets available for interdiction operations. 
While some short-term fixes have been taken, the longer-term implications of further declines in the availability of monitoring and interdiction assets have not been addressed.

Developing performance measures-linking interdiction operations in the transit zone to disrupting the illicit drug market, specifically the cocaine market - is difficult. Nevertheless, the Coast Guard, CBP, and Defense, in conjunction with ONDCP, should develop and coordinate performance measures that more directly relate to transit zone operations. Data compiled by the U.S. Interdiction Coordinator and vetted by the principal agencies involved in transit zone interdiction efforts — data primarily documenting detections of drug movements and seizures and disruptions of illicit drugs_-could serve as benchmarks for assessing progress until data more directly related to disrupting the illicit drug market can be developed.

Collecting relevant data to assess the effect of interdiction operations on the cocaine market and drug usage in the United States is problematic. Assessing how much cocaine is produced and moves towards the United States is not easy - as the 2004 IACM demonstrates. Most other readily available data on cocaine price, purity, and availability-indicators of U.S. demand-cannot be generalized to the United States. More systematic surveys on drug usage take time-sometimes several years- to complete. Thus, a number of years is often needed to show the effect of a drug policy change. The National Research Council reported similar issues in 2001. However, until ONDCP and other cognizant agencies fully address the Council's recommendations, data to help assess U.S. drug usage will remain problematic.

\section{Recommendations for Executive Action}

We recommend that the Secretaries of Defense and Homeland Security plan for the likely decline in the future availability of ships and aircraft for transit zone interdiction operations and, specifically, determine how they will compensate for the decline in P-3 maritime patrol aircraft availability.

We recommend that the Secretaries of Defense and Homeland Security develop and coordinate, in conjunction with the Director of ONDCP, performance measures for transit zone interdiction operations that take advantage of available drug interdiction data (such as detections, seizures, and disruptions) to provide a basis for (1) assessing transit zone interdiction performance and (2) deciding how to deploy increasingly limited assets, such as the P-3 maritime patrol aircraft. 
We also recommend that the Director of ONDCP address each of the recommendations made by the National Research Council and report to the Congress what departments and agencies need to take action, what remains to be done, and when action is expected to be completed. In those instances where ONDCP reports that action is not necessary, we recommend that it document the reasons why.

\section{Agency Comments and Our Evaluation}

Defense, Homeland Security, and ONDCP provided written comments on a draft of this report. See appendixes III, IV, and V, respectively. Justice and State did not provide written comments. However, we discussed the draft report with cognizant officials at each of the departments. Overall, the departments and ONDCP stated that they generally concurred with the recommendations that applied to them, but none detailed when and how they will address them.

Defense and Homeland Security noted that they already have taken or are in the process of taking appropriate action regarding planning for drug interdiction asset requirements and developing relevant performance measures.

- Defense specifically noted that the U.S. Navy has developed a Fleet Response Plan designed to transition from the P-3 to its replacement aircraft - the Multi-Mission Maritime Aircraft, which is scheduled to be introduced into the fleet in fiscal year 2011. Defense added that it will continue to coordinate with all maritime patrol asset providers in the transit zone. Regarding performance measures, Defense stated that it has appropriate mechanisms in place to assess its efforts. Yet, Defense also noted that during the past year it has coordinated with its commands to develop performance goals, measures, and targets for the transit zone and continues to work with them as they prepare their submissions. During the course of this engagement, cognizant Defense officials stated on several occasions that they had not finalized performance measures. $^{26}$

\footnotetext{
${ }^{26}$ We also note that in 1999, we recommended that Defense develop performance measures for assessing its contributions to counternarcotics' operations. See our report titled Drug Control: Assets DOD Contributes to Reducing the Illegal Drug Supply have Declined, GAO/NSIAD-00-9 (Washington, D.C.: Dec. 21, 1999).
} 
- Homeland Security stated it develops asset requirements as part of an interagency process where asset commitment is based on threat level and the availability of funding. While it remains committed to "robust support" of maritime transit zone interdiction efforts, unforeseen events-Hurricane Katrina, for example — can affect asset availability. Regarding performance measures, Homeland Security noted that as a result of the Intelligence Reform and Terrorism Prevention Act of $2004,{ }^{27}$ it has undertaken an effort to develop and coordinate a performance measurement system to better assess Homeland Security's counternarcotics' activities, including transit zone interdiction operations. Homeland Security did not state when it will complete this effort.

ONDCP did not comment directly on interdiction asset availability, but overall, ONDCP agreed that developing performance measures that link interdiction operations to disrupting the cocaine market is difficult but necessary, and stated that it will work with Defense and Homeland Security within the framework of the Government Performance and Results Act to develop appropriate measures.

Our recommendation regarding planning for the likely decline in interdiction asset availability was intended to have Defense and Homeland Security work together to address asset availability; in particular, the decline in maritime patrol aircraft hours. However, the departments do not address in their comments when or how their planning efforts have been coordinated nor when their on-going efforts will be completed. We continue to believe that such a coordinated planning effort is both appropriate and necessary to ensure that the departments' limited assets are used in the most effective manner, and encourage the departments to follow through with one another.

Concerning the National Research Council's recommendations, ONDCP did not specifically address our recommendation to report to Congress on what actions have been taken or still need to be taken. Rather, ONDCP referred to a 2001 study-Measuring the Deterrent Effect of Enforcement Operations on Drug Smuggling, 1991-1999 — that it published as one of several steps it has taken to address the Council's recommendations. We note that the ONDCP study was published the same year the Council published its report, and that it does not refer to the Council's report or its

${ }^{27}$ Pub. L. 108-458, 118 Stat. 3638. 
recommendations. The ONDCP study's primary objective was to "measure the impact of drug enforcement operations on the cocaine smuggling industry." Among other things and related to this report, the study concludes that better data was available on what drug traffickers were doing than on the activities of U.S. drug interdiction assets. According to the study's authors, "this was most notably the case with the interdiction activities of the Department of Defense." In addition, to address the Council's recommendations, ONDCP also noted that it has established two operational priorities focused on (a) understanding the drug market and (b) enhancing the data sets ONDCP relies on. These priorities were initiated during the course of our engagement. According to ONDCP officials, they have not been completed.

As we note in this report, collecting relevant data for assessing the effect of interdiction operations on the cocaine market and U.S. illicit drug usage is problematic. But more than three years after the National Research Council's report addressing the illicit drug data issue was finalized, ONDCP cannot point to any specific action it has completed to address the Council's recommendations for improving the collection of illicit drug trafficking and usage data. Given the importance of the illicit drug problem and the on-going controversy in the United States about how best to confront it, better data for evaluating alternative drug control policies is paramount. We continue to urge ONDCP to follow up on the Council's findings and recommendations and take the steps necessary to address the continuing shortcomings in its illicit drug data and report to Congress the status of its efforts.

In commenting on the IACM, Homeland Security stated that the decision by the interagency group to report a range for cocaine movement was a wise one because it acknowledged the lack of precision inherent in the data that is currently available. We agree, and did not intend to imply anything else. We also agree with Homeland Security that greater efforts need to be made to improve the methodology and integrity of data instruments in order to gain a better and more useful understanding of drug production and consumption.

Finally, all the departments and ONDCP provided additional information on various aspects of their roles regarding drug interdiction in the transit zone. Defense, in particular, emphasized that it is not authorized to conduct law enforcement operations but can support them. In addition, all the departments and ONDCP provided us technical comments and updates that we have incorporated throughout the report, as appropriate. 
As agreed with your office, unless you publicly announce its contents earlier, we plan no further distribution of this report until 30 days from the date of this letter. At that time, we will send copies of this report to interested congressional committees and the Secretaries of Defense, Homeland Security, Justice, and State, and the Director of ONDCP. We will also make copies available to others upon request. In addition, this report will be available at no charge on the GAO Web site at http://www.gao.gov.

If you or your staff have any questions concerning this report, please contact me at (202) 512-4268 or FordJ@gao.gov. Contact points for our Offices of Congressional Relations and Public Affairs may be found on the last page of this report. Key contributors to this report were $\mathrm{Al}$ Huntington, Joe Carney, J.J. Marzullo, José Peña, and Jim Strus.

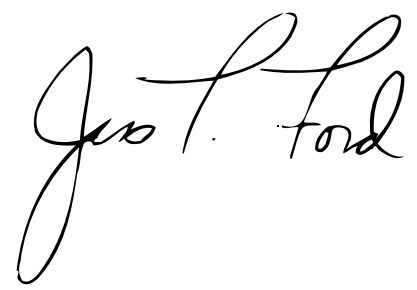

Jess T. Ford, Director

International Affairs and Trade 


\section{Scope and Methodology}

Overall, to examine the status of U.S. interdiction assets and progress made in disrupting drug trafficking in the transit zone, we focused on U.S. (1) efforts to interdict cocaine because nearly all the cocaine entering the United States comes from South America and (2) operations in the western Caribbean Sea and the eastern Pacific Ocean because the United States has positioned most of its interdiction assets in these areas. We also agreed with the requesters to limit the scope of this engagement by examining U.S. operations to interdict cocaine before it reaches intermediate staging points in the Caribbean Sea, Central America, and Mexico on the way to the United States. We further narrowed our examination to U.S. efforts to detect and disrupt unscheduled maritime movements of cocaineprimarily go-fast boats, but also fishing and other types of ocean-going vessels. Although drug traffickers use small aircraft to transport cocaine and other drugs, the United States essentially relies on the law enforcement authorities in the countries where they land to interdict them.

To track the changes in the amounts of cocaine seized and disrupted since calendar year 2000, we relied on the Interagency Assessment of Cocaine Movement (IACM). While the data sets used to prepare the IACM have been called into question by the interagency group that prepares it, the IACM data on cocaine seizures and disruptions are based on the Consolidated Counterdrug Database, which is managed by the Office of the U.S. Interdiction Coordinator. Beginning with 2004, the Coordinator's Office began using stricter rules to vet the data on drug movements, detections, seizures, and disruptions in quarterly meetings with the interagency drug community. The intent was to minimize duplicate or questionable reported drug movements. According to the database manager, however, the more careful review of the data did not materially affect the categorization or number of maritime drug movements-our primary emphasis. Rather, many suspect aircraft are no longer counted as drug movement events unless corroborating information strongly suggests drugs were aboard the aircraft. We observed a quarterly vetting session and discussed the process for determining whether reported drug events can be "confirmed and substantiated" based on intelligence and other sources with several members of the interagency group that participate, including the Defense Intelligence Agency (DIA); the U.S. Director of Central Intelligence, Crime and Narcotics Center; the Drug Enforcement Administration (DEA); the Joint Interagency Task Force-South (JIATF-South); the Coast Guard; and Customs and Border Protection (CBP). Based on the foregoing, we determined that the cocaine seizure and disruption data provided to us were sufficiently reliable for describing and documenting trends in the transit zone. 

seizures and disruptions, we reviewed the IACMs for calendar years 2000 through 2004. We discussed the observations made in the IACMs and reported operational changes since 2000 with cognizant officials in the Office of National Drug Control Policy (ONDCP), the Department of Defense's (Defense) Office of Drug Enforcement Policy and Support, and other members of the interagency counternarcotics community-namely, DIA, the Crime and Narcotics Center, DEA, JIATF-South, and the U.S. Interdiction Coordinator.

To analyze the trends in the assets provided by the United States and its allies since fiscal year 2000 to support illicit drug interdiction in the transit zone, we relied on data provided by JIATF-South and JIATF-West that tabulates on-station ship days and flight hours spent on interdiction missions by the provider and the type of ship or aircraft. ${ }^{1}$ Until fiscal year 2004, JIATF-West had responsibility for U.S. drug detection and monitoring activities in the eastern Pacific Ocean off the coast of Mexico. ${ }^{2}$ We analyzed data for fiscal years 2000 through 2005, although JIATF-West could not provide information about on-station ship days for the first quarter of fiscal year 2000 (September-December 1999). ${ }^{3}$ Compared to the first quarter of 2001, JIAFT-West's contribution was about 5.4 percent of the total ship days on station. To determine the reliability of the JIATF-South and JIATF-West data, we discussed how the respective data was compiled with cognizant officials and compared it to available-albeit, less specific-data from the Coast Guard, CBP, and Defense. Through these efforts, we determined that

\footnotetext{
${ }^{1}$ As we reported in 2002 (GAO-02-13), none of the departments or agencies involved in transit zone interdiction operations track the costs directly associated with cocaine interdiction missions nor do they track the ship or flight time spent on interdiction versus other missions in the transit zone. In addition, the Coast Guard, CBP, and Defense could not separate the time spent traveling to the transit zone-in the case of ships this could be several days or a week-versus actually conducting their missions.

${ }^{2}$ Through fiscal year 2003, JIATF-West was located in Alameda, California. It has since moved to Honolulu, Hawaii.

${ }^{3}$ We also noted that the Coast Guard conducted an operation in the eastern Caribbean Sea independent of JIATF-South that included illicit drug interdiction (known as "Operation Frontier Shield"). According to the Coast Guard, the operation was ongoing in fiscal year 2000, but we did not include it in our analysis because the Coast Guard could not separate the time needed for its ships and aircraft to move to the operational area, nor could it identify the time its ships and aircraft spent on drug interdiction versus other objectives, such as stemming the flow of illegal aliens.
} 
the data provided to us were sufficiently reliable for describing the trends in asset availability during fiscal years 2000 through 2005.

To determine the challenges facing the departments and agencies in maintaining current levels of transit zone interdiction operations, we reviewed issues raised in the IACM and other department and agency planning and budgeting documents. We discussed these matters with cognizant law enforcement and military authorities at Defense, Department of Homeland Security, Department of Justice, and headquarters in Washington, D.C. We also discussed operational challenges with

- Coast Guard officials at their base in Jacksonville, Florida, where the Coast Guard stations armed helicopters used in interdiction operations;

- CBP officials at their base in Jacksonville, Florida, where CPB stations P-3 maritime patrol aircraft used in interdiction operations;

- DEA officials in Miami, Florida, and Nassau, Bahamas, who manage an ongoing drug interdiction program in the waters around the Bahamas called "Operation Bahamas, and Turks and Caicos;"

- JIATF-South officials in Key West, Florida, including the Commander; representatives from the Coast Guard, CBP, Defense, and other U.S. agencies; as well as the liaison officers from France, the Netherlands, and the United Kingdom; and

- Justice officials with the U.S. Attorney's offices in Tampa and Sarasota, Florida, directly involved in the Panama Express operation.

To determine how the Coast Guard, CBP, and Defense assess their performance, we met with cognizant officials in their respective planning and budgeting offices and reviewed relevant reports and related documents. Since only the Coast Guard had completed developing performance measures, we relied on discussions with the key officials to document what $\mathrm{CBP}$ and Defense were developing. To determine what data are available for assessing transit zone performance, we met with the principals involved in preparing the IACM. We discussed issues that have arisen concerning cultivation and production estimates (primarily, officials with the Crime and Narcotics Center and DEA), as well as interdiction amounts (primarily, the U.S. Interdiction Coordinator's Consolidated Counterdrug Database manager). In addressing usage and demand estimates in the United States, we asked ONDCP officials what they used to 
Appendix I

Scope and Methodology

measure progress against the National Drug Control Strategy's goal of reducing drug usage in the United States. These officials cited the data sources we refer to in the body of the report (see table 4) and described how they used the information. We also reviewed the scope and methodology statements for each data source, and in the cases of the National Survey on Drug Use and Health and Monitoring the Future, we spoke with the current project directors to obtain their views. 


\section{Counternarcotics Maritime Law Enforcement Agreements}

The United States has signed Counternarcotics Maritime Law Enforcement agreements with 25 countries in the transit and source zones-three since 2000 after the United States closed its military installations in Panama. According to Coast Guard officials, these agreements have improved cooperation with nations in the region and increased U.S. and, in particular, the Coast Guard's capability to board suspect vessels and detain suspected drug traffickers. These officials added that these agreements are one of the primary reasons for increased interdictions of cocaine shipments in the transit zone. These bilateral agreements typically have six provisions to them. The United States and the countries negotiate each provision separately, which means that some countries may agree to some provisions and not others. The six parts provide for the following:

- Shipboarding provisions allow U.S. agencies under certain conditions to stop, board, and search suspicious vessels registered in that country without having specific permission.

- Shiprider provisions permit countries to place law enforcement officials on another's vessels.

- Pursuit provisions allow U.S. law enforcement agencies, under very limited circumstances, to pursue aircraft and vessels in a country's airspace and territorial waters. In particular, the provisions permit U.S. law enforcement agencies to board and search a suspect vessel if the country does not have a vessel or aircraft available to respond immediately.

- Entry-to-investigate provisions allow the U.S. law enforcement agencies, under very limited circumstances, to enter a country's airspace or territorial waters to investigate aircraft or vessels suspected of illicit drug trafficking. Specifically, the provisions permit U.S. law enforcement agencies to board and search a suspect vessel if the country does not have a vessel or aircraft available to respond immediately.

- Overflight provisions permit the U.S. law enforcement aircraft to fly over the country's territorial waters, with appropriate notice to the country's coastal authorities.

- Relay order-to-land provisions allow U.S. law enforcement agencies to relay an order to land from the host country to the suspect aircraft. 
Appendix II

Counternarcotics Maritime Law

Enforcement Agreements

Moreover, an additional International Maritime Interdiction Support clause permits U.S. law enforcement agencies, principally the Coast Guard, to transport suspected drug traffickers through that country to the United States for prosecution and provides for expedited access to that country's dockside facility to search suspect vessels. Since 2000, the United States has entered into support clauses with eight additional countries.

The following table lists the law enforcement agreements, including the international maritime interdiction support clause that the United States has negotiated with countries in the transit and source zones.

Table 5: Counternarcotics Maritime Law Enforcement Agreements with Countries in the Source and Transit Zones

\begin{tabular}{|c|c|c|c|c|c|c|c|}
\hline Country & Shipboarding & Shiprider & Pursuit & $\begin{array}{l}\text { Entry-to- } \\
\text { Investigate }\end{array}$ & Overflight & $\begin{array}{r}\text { Relay } \\
\text { order- } \\
\text { to-land }\end{array}$ & $\begin{array}{r}\text { International } \\
\text { Maritime } \\
\text { Interdiction } \\
\text { Support clause }\end{array}$ \\
\hline 1. Antigua and Barbuda & $\mathrm{X}$ & $\mathrm{X}$ & $X$ & $\mathrm{X}$ & $\mathrm{X}$ & $x$ & * \\
\hline 2. Bahamas & & $x$ & & & $\mathrm{X}$ & $\mathrm{X}$ & \\
\hline 3. Barbados & $x$ & $x$ & $x$ & $x$ & $x$ & $\mathrm{X}$ & \\
\hline 4. Belize & $x$ & $x$ & $x$ & $x$ & $x$ & $x$ & \\
\hline 5. Colombia & $x$ & & & & & & \\
\hline 6. Costa Rica & $x$ & $x$ & $x$ & $X$ & $x$ & $x$ & * \\
\hline 7. Dominica & $x$ & $x$ & $x$ & $x$ & & & \\
\hline 8. Dominican Republic & $x$ & $x$ & $x$ & $x$ & * & * & * \\
\hline 9. Ecuador & & & & & $x$ & & \\
\hline 10. El Salvador & & & & & $x$ & & * \\
\hline 11. Grenada & $x$ & $x$ & $x$ & $x$ & $x$ & $x$ & \\
\hline 12. Guatemala & * & * & * & * & * & * & * \\
\hline 13. Haiti & * & * & $x$ & $x$ & $x$ & * & \\
\hline 14. Honduras & * & * & * & * & * & * & * \\
\hline 15. Jamaica & $x$ & $x$ & $X$ & $x$ & $x$ & $x$ & \\
\hline $\begin{array}{l}\text { 16. Netherlands Antilles } \\
\text { and Aruba }\end{array}$ & & $x$ & $x$ & $x$ & $x$ & & \\
\hline 17. Nicaragua & * & * & * & * & * & * & * \\
\hline 18. Panama & * & $x$ & * & * & * & * & * \\
\hline 19. St. Kitts and Nevis & $x$ & $x$ & $x$ & $x$ & $x$ & $\mathrm{X}$ & \\
\hline 20. St. Lucia & $x$ & $\mathrm{X}$ & $\mathrm{X}$ & $x$ & $x$ & $x$ & \\
\hline $\begin{array}{l}\text { 21. St. Vincent and } \\
\text { Grenadines }\end{array}$ & $x$ & $x$ & $x$ & $x$ & & & \\
\hline
\end{tabular}


Appendix II

Counternarcotics Maritime Law

Enforcement Agreements

(Continued From Previous Page)

\begin{tabular}{|c|c|c|c|c|c|c|c|}
\hline Country & Shipboarding & Shiprider & Pursuit & $\begin{array}{l}\text { Entry-to- } \\
\text { Investigate }\end{array}$ & Overflight & $\begin{array}{l}\text { Relay } \\
\text { order- } \\
\text { to-land }\end{array}$ & $\begin{array}{r}\text { International } \\
\text { Maritime } \\
\text { Interdiction } \\
\text { Support clause }\end{array}$ \\
\hline 22. Suriname & $\mathrm{X}$ & $x$ & $x$ & $x$ & $x$ & $x$ & \\
\hline 23. Trinidad and Tobago & $\mathrm{X}$ & $X$ & $X$ & $\mathrm{x}$ & $X$ & $\mathrm{X}$ & \\
\hline 24. Turks and Caicos & & $X$ & & & & & \\
\hline 25. Venezuela & $x$ & & $x$ & & & & \\
\hline
\end{tabular}


Mr. Jess T. Ford

Director

International Affairs and Trade Issues

U.S. Government Accountability Office

441 G Street, N.W.

Washington, D.C. 20548

Dear Mr. Ford:

This is the Department of Defense (DoD) response to the GAO draft report, GAO-06-200, "DRUG CONTROL: Agencies Need to Plan for Likely Declines in Drug Interdiction Assets, and Develop Better Performance Measures for Transit Zone Operations," dated October 20, 2005 (GAO Code 320307).”

The enclosed DoD response to the GAO recommendations is provided for incorporation with this letter as an appendix to the final report.

Thank you for the opportunity to review this draft report and to provide formal comments. Should you have any questions concerning this response, please do not hesitate to contact me at (703) 697-3186.

Sincerely,

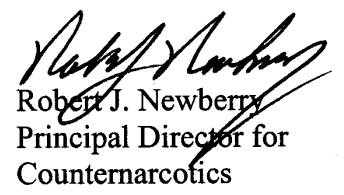

Enclosure:

As stated 
Appendix III

Comments from the Department of Defense

\title{
GAO DRAFT REPORT - DATED October 20, 2005 GAO CODE 320307/GAO-06-200
}

\author{
"DRUG CONTROL: Agencies Need to Plan for Likely Declines in Drug Interdiction \\ Assets, and Develop Better Performance Measures for Transit Zone Operations"
DEPARTMENT OF DEFENSE COMMENTS TO THE RECOMMENDATIONS

Now on page 30.

RECOMMENDATION 1: The GAO recommended that the Secretary of Defense plan for the likely decline in the future availability of ships and aircraft for transit zone interdiction operations and, specifically, determine how they will compensate for the decline in P-3 Maritime Patrol Aircraft (MPA) availability. (p. 33/GAO Draft Report)

DOD RESPONSE: Partially Concur. Sustaining DoD's war-fighting requirements while the U.S. Navy (USN) transitions from the P-3C aircraft to the Multi-Mission Maritime Aircraft (MMA) remains one of our highest priorities. This transition has been complicated by the discovery of accelerated structural fatigue issues affecting our P-3 fleet and our on-going commitment to the Global War on Terrorism. In response to these challenges, the USN has developed a Fleet Response Plan designed to husband limited P-3 resources and bridge the gap until the MMA begins introduction in FY11.

The decline in DoD P-3C aircraft mentioned in the GAO report is a result of this Fleet Response Plan and should not be interpreted as either an unexpected shortfall or a lack of DoD resolve. We recognize that this represents a challenge to Transit Zone operations and have worked extensively with our partner nations and within the USG interagency to leverage our collective MPA assets. We have invested in technologies to improve our sorting and cueing capabilities which enhance our detection and monitoring mission. Additionally, we have assisted Transit Zone countries to develop indigenous capabilities to detect, monitor, and interdict narcotics trafficking conveyances. DoD will continue to coordinate with all MPA force providers (USG and partner nations) committed to disrupting the flow of illegal narcotics through the Transit Zone.

RECOMMENDATION 2: The GAO recommended that the Secretary of Defense develop and coordinate in conjunction with the Director of the Office of National Drug Control Policy (ONDCP), performances measures for transit zone interdiction operations that take advantage of available drug interdiction data to provide basis for: (a) assessing

Now on page 30 . transit zone interdiction performance and (b) deciding how to deploy increasingly limited assets, such as the P-3 maritime patrol aircraft. (p. 33/GAO Draft Report)

DOD RESPONSE: Partially Concur. Over the past year, DoD has coordinated with commands to develop performance goals, measures and targets for the Transit Zone. We 
Appendix III

Comments from the Department of Defense

continue to work with the commands as they prepare their submissions. Where possible, we have incorporated existing measures to assess DoD's roles within the Transit Zone, which includes detection and monitoring, limited intelligence, partner nation training, and mobility support to law enforcement. We feel we have appropriate mechanisms in place to assess our efforts. However, we will continue to work with ONDCP to modify our efforts, as appropriate.

The GAO refers to interdiction operations throughout the draft report. As a matter of accuracy, DoD is not authorized to conduct law enforcement interdiction operations. It can, however, provide support to law enforcement as they conduct interdiction operations. Consequently, as it applies to DoD and for purposes of measuring success, the correct terms are detection and monitoring. Finally, although DoD willingly consults with ONDCP and other interagency partners as recommended in the report, it reserves final decision on the deployment of DoD assets. 


\section{Comments from the Department of Homeland Security}

\section{Homeland} Security

November 7, 2005

Mr. Jess T. Ford

Director, International Affairs and Trade U.S. Government Accountability Office 441 G Street, NW

Washington, DC 20548

Dear Mr. Ford:

RE: Draft Report GAO-06-200, Drug Control: Agencies Need to Plan for Likely Declines in Drug Interdiction Assets, and Develop Better Performance Measures for Transit Zone Operations (GAO Job Code 320307)

The Department of Homeland Security (DHS) appreciates the opportunity to review and comment on the Government Accountability Office's (GAO) draft report. The report presents a generally fair and accurate description of the Department's noncommercial maritime transit zone interdiction activities and resource issues. While we generally agree with the recommendations made in the report, DHS believes it is useful to clarify our understanding of the recommendations.

The report calls on the Departments of Defense and DHS to develop plans to compensate for likely declines in interdiction asset availability. DHS develops its drug interdiction asset requirements as part of an interagency planning process where asset commitment is based on the threat level and availability of funding. Despite planning efforts, unforeseen events such as Hurricane Katrina relief efforts may temporarily impact asset availability. DHS continues to be committed to the robust support of the nation's noncommercial maritime transit zone drug interdiction efforts in conjunction with its interagency and international interdiction partners.

In addition, the report calls for the development and coordination of performance measures to better assess transit zone interdiction operations. DHS is cognizant of its responsibilities, in accordance with the Intelligence Reform and Terrorism Prevention Act of 2004, in the area of performance measurement. DHS has - through a management directive - made clear that the responsibility for the development of performance measurements rests with the DHS Office of Counternarcotics Enforcement (DHS-CNE). DHS-CNE currently is undertaking an effort to develop and coordinate a performance measurement system to better assess DHS counter drug activities, including transit zone interdiction operations. The Department of Homeland Security is pleased to note the 
Appendix IV

Comments from the Department of Homeland

Security

report's positive references to the Consolidated Counterdrug Database (CCDB) and its endorsement of the concept of using CCDB data to serve as one of the primary data instruments for assessing progress of interdiction efforts.

Finally, GAO recommends that the Office of National Drug Control Policy (ONDCP) address recommendations of the National Research Council to improve illicit drug data. DHS defers to ONDCP for comment regarding this recommendation.

In addition to commenting on GAO's recommendations, DHS would like to address an issue related to the data reporting. The GAO report notes that the ONDCP 2004 Interagency Assessment of Cocaine Movement (IACM) reported that "between 325 metric tons and 675 metric tons of cocaine may be moving towards the United States in 2004." Referring to these figures, the GAO report states, "Such a wide range is not useful for assessing transit zone interdiction efforts." DHS believes that the decision to publish a range rather than a single numerical estimate in the 2004 IACM was a wise one because it acknowledges the lack of precision inherent in the data that is currently available. DHS believes that given the current inability to identify a narrow estimate of cocaine production, the publication of a single point estimate figure would have implied a level of precision that simply does not exist and, as a result, would have misled policymakers. In our view, it is important that efforts be made to improve the methodology and integrity of data instruments in order to gain a better and more useful understanding of drug production and consumption. This will give policymakers improved information for determining how to deploy interdiction assets to stop the flow of illicit drugs into the country.

We are available to discuss our response if you have any questions. Technical comments are being provided under separate cover.

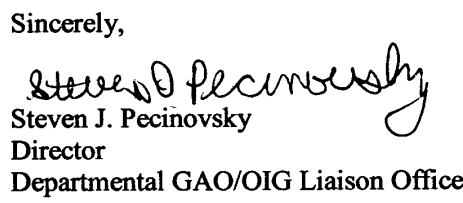




\section{Comments from the Office of National Drug Control Policy}

\section{EXECUTIVE OFFICE OF THE PRESIDENT \\ OFFICE OF NATIONAL DRUG CONTROL POLICY \\ Washington, D.C. 20503}

November 4, 2005

Mr. Jess Ford

Director, International Affairs and Trade Issues

Government Accountability Office

441 G Street, NW

Washington, DC 20548-0001

Dear Mr. Ford:

Thank you for the opportunity to comment on the draft GAO 06-200 report entitled Drug Control: Agencies Need to Plan for Likely Declines in Drug Interdiction Assets, and Develop Better Performance Measures for Transit Zone Operations. You have addressed a complex situation that has changed dramatically over a 5-year period. While you have noted a slight decline in the amount of available transit zone assets, this has been offset through improved interagency cooperation, centralized command and control, and an enhanced intelligence cuing process

In 2003, the United States and our allies seized or forced the jettisoning of 157 metric tons of cocaine headed through the transit zone before it could reach U.S. consumers. In 2004, those figures rose to 196 metric tons Thus far in 2005, Joint Interagency Task Force-South has seized or caused the disruption of more than 190 metric tons of cocaine and is on course for another record breaking year. That this occurred despite periodic redeployments of interdiction forces to cover homeland security missions is strong testament to the crucial role of intelligence and strong interagency support. Specifically, the Departments of Homeland Security and Defense have maintained interdiction force structure commitments despite the demands of other homeland security missions and the war on terror. That said, we are constantly striving to improve our process.

We agree with your assessment that developing performance measures that link interdiction operations in the transit zone to the disruption of the cocaine market is a difficult but necessary task. We will work with the Departments of Defense and Homeland Security to develop and implement performance measures consistent with the Government Performance and Results Act's approach of managerial flexibility. We will continue to seek appropriate measures for individual programs and monitor the overall effect on the ultimate indicator of successdecreasing drug use among youth and adults.

We also agree with your assessment that collection of relevant data to assess the effect of interdiction operations on the cocaine market and drug usage in the United States is challenging. As you note, the 2001 study by the National Research Council (NRC) contained similar conclusions. We have taken several steps to address issues identified by the NRC to include publishing a 2001 study entitled Measuring the Deterrent Effect of Enforcement Operations on Drug Smuggling, 1991-1999 and establishing two operational priorities focused on understanding the illicit drug market and enhancing our data sets.

Once again, we appreciate the opportunity to review this report and believe that we are on the right course concerning your recommendations.

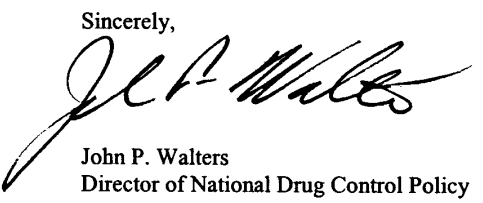




\section{GAO’s Mission}

The Government Accountability Office, the audit, evaluation and investigative arm of Congress, exists to support Congress in meeting its constitutional responsibilities and to help improve the performance and accountability of the federal government for the American people. GAO examines the use of public funds; evaluates federal programs and policies; and provides analyses, recommendations, and other assistance to help Congress make informed oversight, policy, and funding decisions. GAO's commitment to good government is reflected in its core values of accountability, integrity, and reliability.

\section{Obtaining Copies of GAO Reports and Testimony}

The fastest and easiest way to obtain copies of GAO documents at no cost is through GAO's Web site (www.gao.gov). Each weekday, GAO posts newly released reports, testimony, and correspondence on its Web site. To have GAO e-mail you a list of newly posted products every afternoon, go to www.gao.gov and select "Subscribe to Updates."

\section{Order by Mail or Phone}

The first copy of each printed report is free. Additional copies are $\$ 2$ each. A check or money order should be made out to the Superintendent of Documents. GAO also accepts VISA and Mastercard. Orders for 100 or more copies mailed to a single address are discounted 25 percent. Orders should be sent to:

U.S. Government Accountability Office

441 G Street NW, Room LM

Washington, D.C. 20548

To order by Phone: Voice: (202) 512-6000

TDD: (202) 512-2537

Fax: (202) 512-6061

\section{To Report Fraud, Waste, and Abuse in Federal Programs}

Congressional Relations

\section{Contact:}

Web site: www.gao.gov/fraudnet/fraudnet.htm

E-mail: fraudnet@gao.gov

Automated answering system: (800) 424-5454 or (202) 512-7470

\section{Public Affairs}

Gloria Jarmon, Managing Director, JarmonG@gao.gov (202) 512-4400 U.S. Government Accountability Office, 441 G Street NW, Room 7125 Washington, D.C. 20548

Paul Anderson, Managing Director, AndersonP1@gao.gov (202) 512-4800 U.S. Government Accountability Office, 441 G Street NW, Room 7149 Washington, D.C. 20548

PRINTED ON 